\title{
Polymeric "Clickase" Accelerates the Copper Click Reaction of Small Molecules, Proteins, and Cells
}

\author{
Junfeng Chen, ${ }^{\dagger}$ Jiang Wang, ${ }^{\dagger} \mathrm{Ke} \mathrm{Li},{ }^{\dagger}$ Yuhan Wang, ${ }^{\S}$ Martin Gruebele, ${ }^{\dagger, \star,}{ }^{\ddagger}$ Andrew \\ L. Ferguson, " and Steven C. Zimmerman*,†,\& \\ ${ }^{\dagger}$ Department of Chemistry, University of Illinois, Urbana, Illinois 61801, United States. \\ Department of Physics, University of Illinois, Urbana, Illinois 61801, United States.

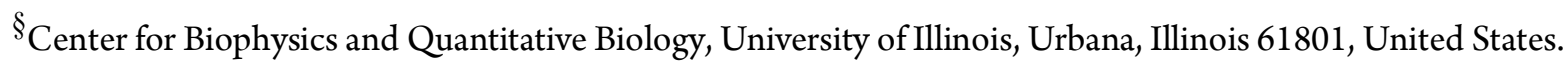 \\ IInstitute for Molecular Engineering, The University of Chicago, Chicago, Illinois 60637, United States.
}

\section{Contents}

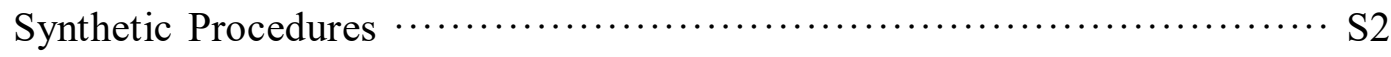

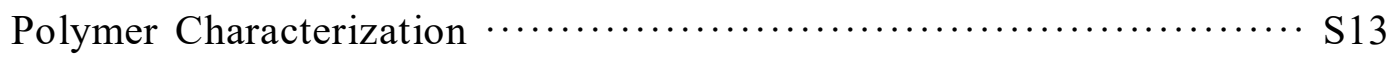

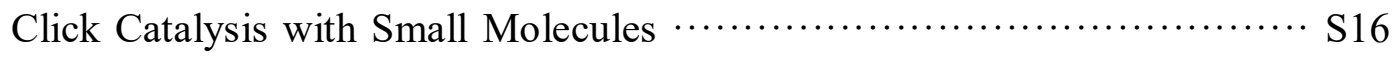

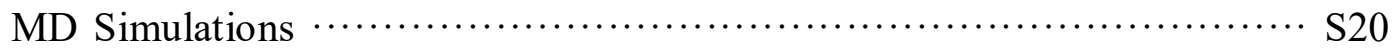

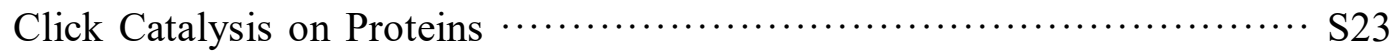

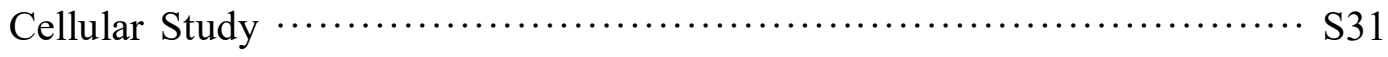

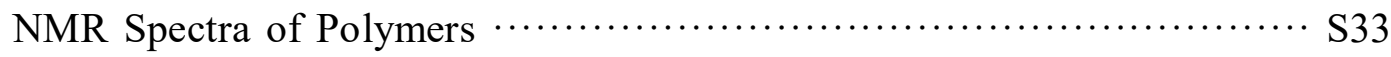

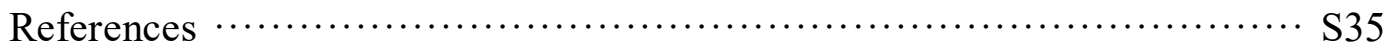




\section{Synthetic Procedures}

\section{tert-Butyl(10-aminodecyl)carbamate}

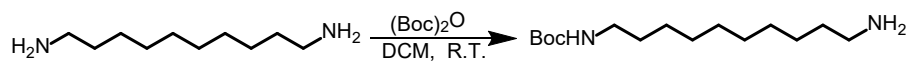

In a $500 \mathrm{~mL}$ two-neck flask, $20.7 \mathrm{~g}(120 \mathrm{mmol})$ of decane-1,10-diamine was dissolved in DCM with magnetic stirring, and a solution of $8.73 \mathrm{~g}(40.0 \mathrm{mmol})$ of (Boc $)_{2} \mathrm{O}$ in $100 \mathrm{~mL}$ of DCM was added dropwise over $2 \mathrm{~h}$ with stirring at room temperature. The mixture was stirred at room temperature overnight. To the solution was added $30 \mathrm{~mL}$ of IPA and washed with $200 \mathrm{~mL}$ of $1 \mathrm{M}$ aqueous $\mathrm{NaOH}$ solution, three times with $200 \mathrm{~mL}$ of water and $100 \mathrm{~mL}$ of brine. The organic layer was dried over $\mathrm{Na}_{2} \mathrm{SO}_{4}$, filtered, and concentrated using a rotary evaporator. The crude product was purified by column chromatography on silica (flash gel) with the 90:10:2 (v/v/v) mixture of DCM, MeOH and ammonium hydroxide (aq) to afford $3.5 \mathrm{~g}$ (35\%) of the title compound as a white solid: ${ }^{1} \mathrm{H}$ NMR $\left(\mathrm{CDCl}_{3}\right.$ and $\left.\mathrm{MeOD}(95: 5, \mathrm{v} / \mathrm{v})\right)$ : $\delta 4.74(\mathrm{~s}, 1 \mathrm{H}), 3.02$ $(\mathrm{m}, 2 \mathrm{H}), 2.86(\mathrm{~s}, 2 \mathrm{H}), 2.63(\mathrm{t}, J=7.2,2 \mathrm{H}), 1.38(\mathrm{~m}, 13 \mathrm{H}), 1.22(\mathrm{~s}, 12 \mathrm{H}) .{ }^{13} \mathrm{C}$ NMR: $\left(125 \mathrm{MHz}, \mathrm{CDCl}_{3}\right.$ and MeOD (95:5, v/v)): $\delta$ 156.3, 79.2, 41.9, 40.8, 33.1, 30.2, 29.7, 29.6, 29.5, 29.4, 28.6, 27.0 (1 missing). High resolution ESI-MS: calculated for $\mathrm{C}_{15} \mathrm{H}_{33} \mathrm{~N}_{2} \mathrm{O}_{2}{ }^{+}\left([\mathrm{M}+\mathrm{H}]^{+}\right)$: 273.2542; found 273.2542.

\section{Mono(10-(14-azaneyl)- $N, N, N$-trimethyldecan-1-aminium) dichloride}

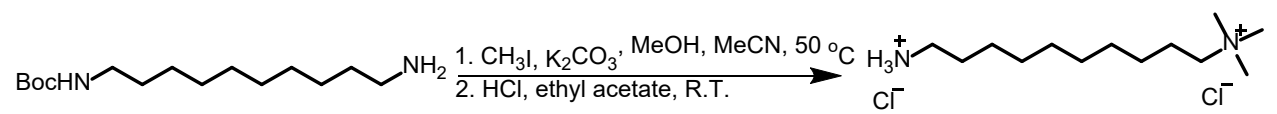

In a $50 \mathrm{~mL}$ round bottom flask, $3.0 \mathrm{~g}(11 \mathrm{mmol})$ of $t$-butyl $(10$-aminodecyl)carbamate was dissolved in a mixture of $6 \mathrm{~mL}$ of $\mathrm{MeOH}$ and $6 \mathrm{ml}$ of $\mathrm{MeCN}$, and $9.1 \mathrm{~g}(66 \mathrm{mmol})$ of $\mathrm{K}_{2} \mathrm{CO}_{3}$ was added to the mixture. The solution was cooled to $0{ }^{\circ} \mathrm{C}$ and $7.8 \mathrm{~g}(55 \mathrm{mmol})$ of $\mathrm{CH}_{3} \mathrm{I}$ was added slowly. The mixture was stirred at room temperature for $4 \mathrm{~h}$, and the temperature was raised to $50{ }^{\circ} \mathrm{C}$ and stirred for another $16 \mathrm{~h}$. The mixture was added to $200 \mathrm{~mL}$ of water and extracted three times with $50 \mathrm{~mL}$ of DCM. The combined organic layer was washed with $100 \mathrm{~mL}$ of water and $100 \mathrm{~mL}$ of brine. The organic layer was dried over $\mathrm{Na}_{2} \mathrm{SO}_{4}$, filtered, and volatiles were removed using a rotary evaporator. The resulting viscous liquid was added with $50 \mathrm{~mL}$ of $1 \mathrm{M} \mathrm{HCl}$ in ethyl acetate was added and stirred at room temperature overnight. The mixture was concentrated using a rotary evaporator to roughly $6-7 \mathrm{~mL}$ and precipitated in $40 \mathrm{~mL}$ of ethyl ether in a $50 \mathrm{~mL}$ centrifuge tube. The precipitate was isolated by centrifugation and the supernatant was discarded. The resulting solid was washed with $45 \mathrm{~mL}$ of ethyl ether for 5 times to afford $2.2 \mathrm{~g} \mathrm{(70 \% )} \mathrm{of}$ the title compound as a yellow power. ${ }^{1} \mathrm{H}$ NMR (DMSO- $\left.d_{6}\right): \delta 8.26(\mathrm{~s}, 1 \mathrm{H}), 3.31(\mathrm{~m}, 2 \mathrm{H}), 3.07(\mathrm{~s}, 9 \mathrm{H})$, $2.71(\mathrm{~m}, 2 \mathrm{H}), 1.66(\mathrm{~m}, 2 \mathrm{H}), 1.56(\mathrm{~m}, 2 \mathrm{H}), 1.27$ (m, 12H). ${ }^{13} \mathrm{C}$ NMR: (125 MHz, DMSO-d6): $\delta$ 65.8, 52.7, 39.3, 29.3, 29.1, 27.5, 26.5, 26.4, 22.69 (1 missing). High resolution ESI-MS: calculated for $\mathrm{C}_{13} \mathrm{H}_{31} \mathrm{~N}_{2}^{+}\left([\mathrm{M}]^{+}\right): 215.2487$; found 215.2497.

\section{$N$-((1-(tert-Butyl)-1H-1,2,3-triazol-4-yl)methyl)- $N$-(prop-2-yn-1-yl)prop-2-yn-1-amine (1)}

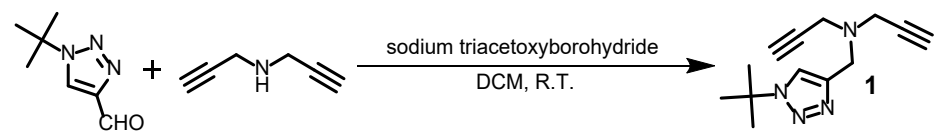


In a $200 \mathrm{~mL}$ round bottom flask, $0.8 \mathrm{~g}(5.2 \mathrm{mmol})$ of 1-(tert-butyl)- $1 H$-1,2,3-triazole-4-carbaldehyde, ${ }^{1} 0.47$ $\mathrm{g}(5.0 \mathrm{mmol})$ of di(prop-2-yn-1-yl)amine and $1.15 \mathrm{~g}(5.4 \mathrm{mmol})$ of sodium triacetoxyborohydride were dissolved in $30 \mathrm{~mL}$ of DCM, and the mixture was stirred at room temperature for $48 \mathrm{~h}$. To the resulting solution was added $30 \mathrm{~mL}$ of $1 \mathrm{M}$ aqueous solution of $\mathrm{H}_{2} \mathrm{SO}_{4}$ and stirred for $15 \mathrm{~min}$. To the mixture was added $15 \mathrm{~g}$ of $\mathrm{K}_{2} \mathrm{CO}_{3}$ adjust the $\mathrm{pH}>8$. The mixture was added with $100 \mathrm{~mL}$ of water and extracted three times with $50 \mathrm{~mL}$ of DCM. The combined organic layer was washed with $100 \mathrm{~mL}$ of brine and dried over $\mathrm{Na}_{2} \mathrm{SO}_{4}$ and filtered. The organic solution was concentrated using a rotary evaporator and purified through silica column chromatograph with DCM:ethyl acetate $(90: 10, \mathrm{v} / \mathrm{v})$ to DCM:MeOH $(95: 5, \mathrm{v} / \mathrm{v})$ to afford $0.82 \mathrm{~g}(71 \%)$ of 1 as a yellow solid. ${ }^{1} \mathrm{H}$ NMR: $\delta 7.61(\mathrm{~s}, 1 \mathrm{H}), 3.88(\mathrm{~s}, 2 \mathrm{H}), 3.51(\mathrm{~d}, J=2.3,4 \mathrm{H}), 2.29(\mathrm{t}, J=$ 2.3, 2H), 1.69 (s, 9H). ${ }^{13} \mathrm{C}$ NMR: (125 MHz): $\delta$ 144.1, 120.1, 78.9, 73.6, 59.5, 48.6, 42.2, 30.3. High resolution ESI-MS: calculated for $\mathrm{C}_{13} \mathrm{H}_{19} \mathrm{~N}_{4}{ }^{+}\left([\mathrm{M}+\mathrm{H}]^{+}\right)$: 231.1610; found 231.1612.

\section{Alkyne Substrates}

The following alkyne substrates and polymer were prepared using the reported procedures. ${ }^{2}$
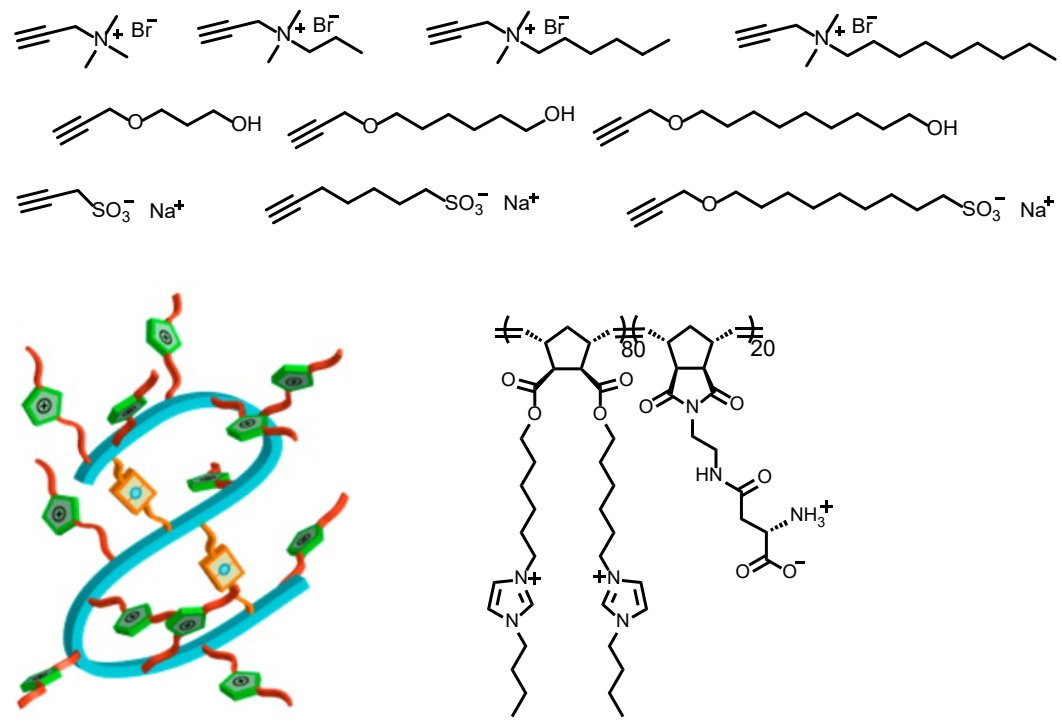

SCNP-1 


\section{Polymer and Nanoparticle Synthesis}

\section{SCNP-2}

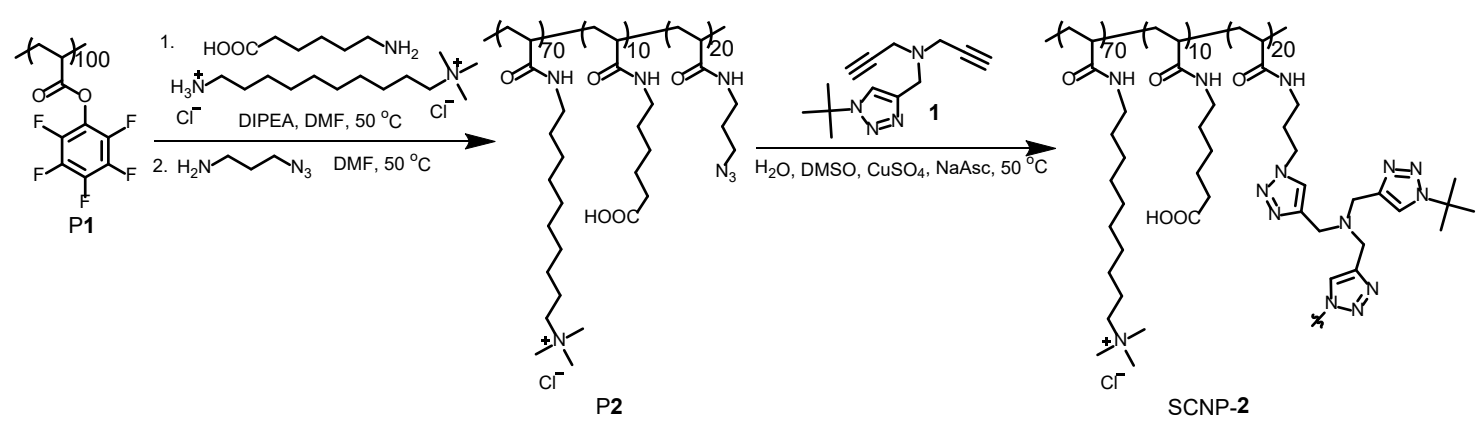

In a $20 \mathrm{~mL}$ screw-cap glass vial, $100 \mathrm{mg}(4.1 \mu \mathrm{mol})$ of P1, $83 \mathrm{mg}(289 \mu \mathrm{mol}, 0.7 \mathrm{eq})$ of mono(10-(14azaneyl)- $N, N, N$-trimethyldecan-1-aminium) dichloride and $5.4 \mathrm{mg}(41 \mu \mathrm{mol}, 0.1 \mathrm{eq})$ of 6-aminohexanoic acid were dissolved in a mixture of $1 \mathrm{~mL}$ of DMF and $100 \mu \mathrm{L}$ of DIPEA. The vial was capped, sealed with parafilm, and stirred at $50^{\circ} \mathrm{C}$ for $3 \mathrm{~h}$. To the mixture, $17 \mathrm{mg}(165 \mu \mathrm{mol}, 0.4 \mathrm{eq})$ of 3-azidopropan-1-amine was added and stirred at $50{ }^{\circ} \mathrm{C}$ for another $3 \mathrm{~h}$. The mixture was cooled to room temperature and precipitated in $14 \mathrm{~mL}$ of ethyl ether in a $15 \mathrm{~mL}$ centrifuge tube. $\mathrm{P} 2$ was collected by centrifugation and the supernatant was discarded. The gel-like solid was redissolved in $1 \mathrm{~mL}$ of $\mathrm{MeOH}$ in the centrifuge tube and $14 \mathrm{~mL}$ of ethyl ether was added to precipitate $\mathbf{P 2}$. The precipitate was collected by centrifugation and supernatant was discarded. This process was repeated twice. The resulting gel-like polymer was dissolved in $3 \mathrm{~mL}$ of water and purified by dialysis ( $1 \mathrm{kD}$ cut-off) with water for $16 \mathrm{~h}$. The resulting solution was lyophilized to afford $\mathrm{P2}$ as a white powder.

In a $300 \mathrm{~mL}$ round bottom flask, $80 \mathrm{mg}(3.0 \mu \mathrm{mol}) \mathrm{P} 2$ and $300 \mu \mathrm{L}$ of $100 \mathrm{mM}$ DMSO solution of 1 were dissolved in $60 \mathrm{~mL}$ of water. To the mixture, $60 \mu \mathrm{L}$ of $100 \mathrm{mM}$ aqueous solution of $\mathrm{CuSO}_{4}$ and $20 \mathrm{mg}$ of sodium ascorbate were added under $\mathrm{N}_{2}$ atmosphere. The mixture was stirred at $30{ }^{\circ} \mathrm{C}$ for $2 \mathrm{~h}$, and the temperature was raised to $50{ }^{\circ} \mathrm{C}$ and stirred overnight. Volatiles were removed using a rotary evaporator and the resulting SCNP-2 was dissolved in $3 \mathrm{~mL}$ of water. To the SCNP-2 solution was added $1 \mathrm{~g}$ of Chelex 100 chelating resin and the mixture was gently shaken overnight to remove copper ions. The resin was removed by filtration. The SCNP-2 solution was purified by dialysis ( $1 \mathrm{kD}$ cut-off) with a $1 \mathrm{M}$ aqueous solution of $\mathrm{NaCl}$ for $8 \mathrm{~h}$ and water for $48 \mathrm{~h}$. The resulting solution was lyophilized to afford SCNP-2 as a white powder. The conversion of each step is almost quantitative and the yield is typically range from 80 $90 \%$ due to losses during the purification. 


\section{SCNP-3}
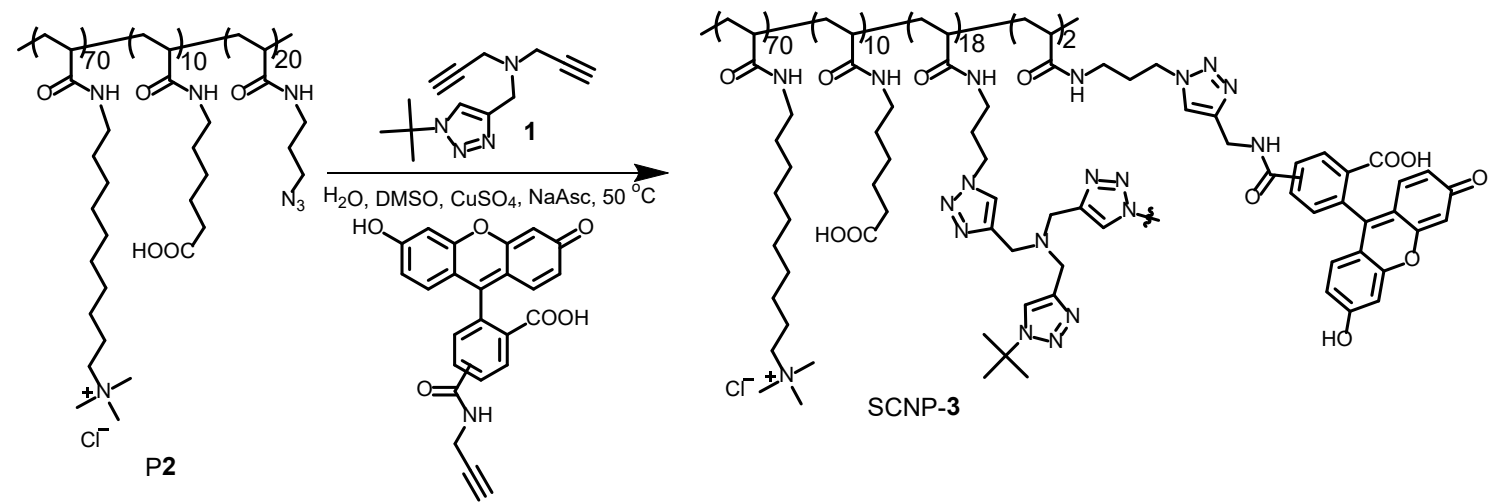

In a $20 \mathrm{~mL}$ screw-cap glass vial, $13.3 \mathrm{mg}(0.5 \mu \mathrm{mol})$ of $\mathbf{P} 2$ and $45 \mu \mathrm{L}$ of $100 \mathrm{mM}$ DMSO solution of $\mathbf{1}$ were dissolved in $10 \mathrm{~mL}$ of water and $10 \mu \mathrm{L}$ of $100 \mathrm{mM}$ DMSO solution of fluorescein with an alkyne group was added. To the mixture, $10 \mu \mathrm{L}$ of $100 \mathrm{mM}$ aqueous solution of $\mathrm{CuSO}_{4}$ and $20 \mathrm{mg}$ of sodium ascorbate were added under $\mathrm{N}_{2}$ atmosphere. The mixture was stirred at $30^{\circ} \mathrm{C}$ for $2 \mathrm{~h}$, and the temperature was raised to $50{ }^{\circ} \mathrm{C}$ and stirred overnight. Volatiles were removed using a rotary evaporator and the resulting SCNP3 was dissolved in $1 \mathrm{~mL}$ of water. The SCNP-3 solution was added with $0.2 \mathrm{~g}$ of Chelex 100 chelating resin and the mixture was gently shaken overnight to remove copper ions. The resin was removed by filtration. The SCNP-3 solution was purified by dialysis ( $1 \mathrm{kD}$ cut-off) with $1 \mathrm{M}$ aqueous solution of $\mathrm{NaCl}$ for $8 \mathrm{~h}$ and water for $48 \mathrm{~h}$. The resulting solution was lyophilized to afford SCNP-3 as a white powder. The conversion of each step is almost quantitative and the yield is typically range from $80-90 \%$ due to losses during the purification.

P3

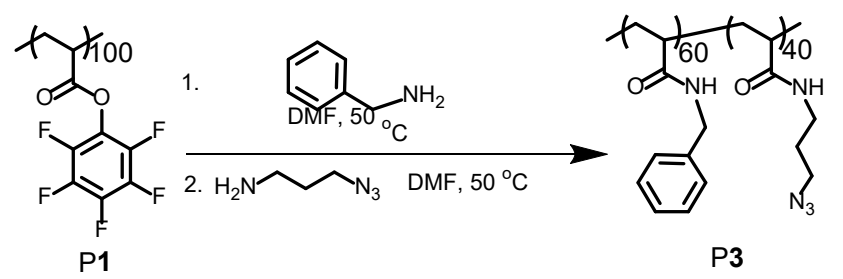

In a $20 \mathrm{~mL}$ screw-cap glass vial, $100 \mathrm{mg}(4.1 \mu \mathrm{mol})$ of P1 and $27 \mathrm{mg}(248 \mu \mathrm{mol}, 0.6 \mathrm{eq})$ of benzylamine were dissolved in $1 \mathrm{~mL}$ of DMF. The vial was capped, sealed with parafilm, and stirred at $50{ }^{\circ} \mathrm{C}$ for $3 \mathrm{~h}$. To the mixture, $33 \mathrm{mg}$ ( $330 \mu \mathrm{mol}, 0.8 \mathrm{eq})$ of 3-azidopropan-1-amine was added and stirred at $50{ }^{\circ} \mathrm{C}$ for another $3 \mathrm{~h}$. The mixture was cooled to room temperature and precipitated in $14 \mathrm{~mL}$ of ethyl ether in a 15 $\mathrm{mL}$ centrifuge tube. $\mathbf{P 3}$ was collected by centrifugation and the supernatant was discarded. The gel-like solid was redissolved in $1 \mathrm{~mL}$ of $\mathrm{MeOH}$ in the centrifuge tube and $14 \mathrm{~mL}$ of ethyl ether was added to precipitate $\mathrm{P3}$. The precipitate was collected by centrifugation, and supernatant was discarded. This process was repeated twice. The polymer was dried using a rotary evaporator to afford $55 \mathrm{mg}(85 \%)$ of $\mathrm{P3}$ as a white solid. 


\section{SCNP-4}

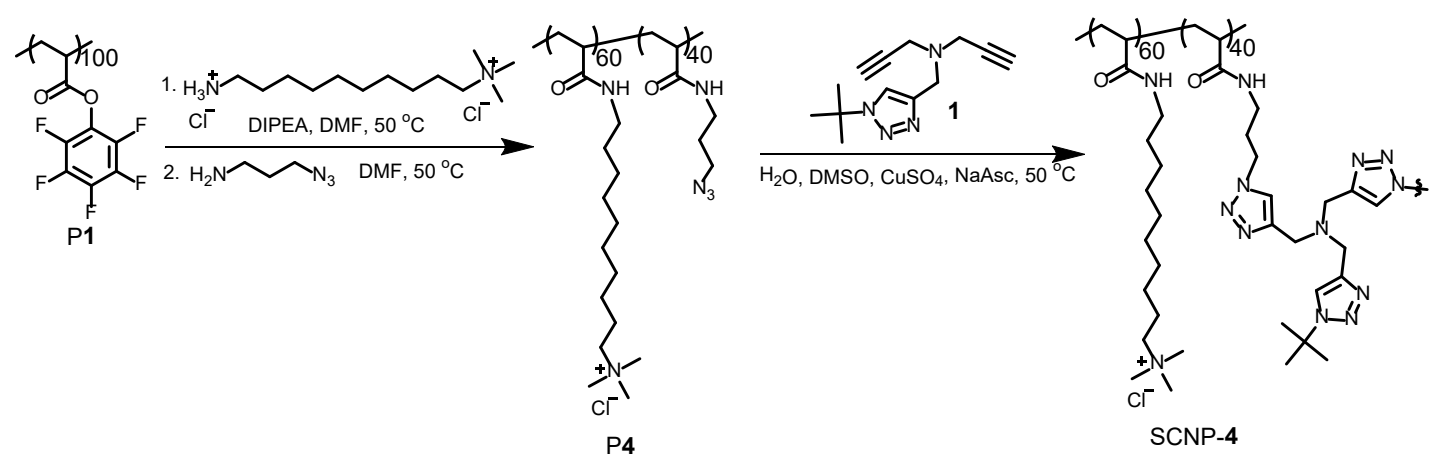

In a $20 \mathrm{~mL}$ screw-cap glass vial, $100 \mathrm{mg}(4.1 \mu \mathrm{mol})$ of P1 and $71 \mathrm{mg}(248 \mu \mathrm{mol}, 0.6 \mathrm{eq})$ of mono(10-(14azaneyl)- $N, N, N$-trimethyldecan-1-aminium) dichloride were dissolved in a mixture of $1 \mathrm{ml}$ of DMF and $100 \mu \mathrm{L}$ of DIPEA. The vial was capped, sealed with parafilm, and stirred at $50{ }^{\circ} \mathrm{C}$ for $3 \mathrm{~h}$. To the mixture, $33 \mathrm{mg}(330 \mu \mathrm{mol}, 0.8 \mathrm{eq})$ of 3-azidopropan-1-amine was added and stirred at $50{ }^{\circ} \mathrm{C}$ for another $3 \mathrm{~h}$. The mixture was cooled to room temperature and precipitated in $14 \mathrm{~mL}$ of ethyl ether in a $15 \mathrm{~mL}$ centrifuge tube. P4 was collected by centrifugation and the supernatant was discarded. The gel-like solid was redissolved in $1 \mathrm{~mL}$ of $\mathrm{MeOH}$ in the centrifuge tube and $14 \mathrm{~mL}$ of ethyl ether was added to precipitate $\mathrm{P4}$. The precipitate was collected by centrifugation, and supernatant was discarded. This process was repeated twice. The resulting gel-like polymer was dissolved in $3 \mathrm{~mL}$ of water and purified by dialysis $(1 \mathrm{kD}$ cutoff) with water for $16 \mathrm{~h}$. The resulting solution was lyophilized to afford $\mathrm{P} 4 \mathrm{as}$ a white powder.

In a $300 \mathrm{~mL}$ round bottom flask, $75 \mathrm{mg}(3.0 \mu \mathrm{mol})$ of $\mathrm{P} 4$ and $600 \mu \mathrm{L}$ of $100 \mathrm{mM}$ DMSO solution of 1 were dissolved in $60 \mathrm{~mL}$ of water. To the mixture, $120 \mu \mathrm{L}$ of $100 \mathrm{mM}$ aqueous solution of $\mathrm{CuSO}_{4}$ and $20 \mathrm{mg}$ of sodium ascorbate were added under $\mathrm{N}_{2}$ atmosphere. The mixture was stirred at $30{ }^{\circ} \mathrm{C}$ for $2 \mathrm{~h}$, and the temperature was raised to $50{ }^{\circ} \mathrm{C}$ and stirred overnight. Volatiles were removed using a rotary evaporator and the resulting SCNP-4 was dissolved in $3 \mathrm{~mL}$ of water. The SCNP-4 solution was added with $1 \mathrm{~g}$ of Chelex 100 chelating resin, and the mixture was gently shaken overnight to remove copper ions. The resin was removed by filtration. The SCNP-4 solution was purified by dialysis ( $1 \mathrm{kD}$ cut-off) with $1 \mathrm{M}$ aqueous solution of $\mathrm{NaCl}$ for $8 \mathrm{~h}$ and water for $48 \mathrm{~h}$. The resulting solution was lyophilized to afford SCNP-4 as a white powder. The conversion of each step is almost quantitative and the yield is typically range from 80 $90 \%$ due to losses during the purification. 


\section{SCNP-5}

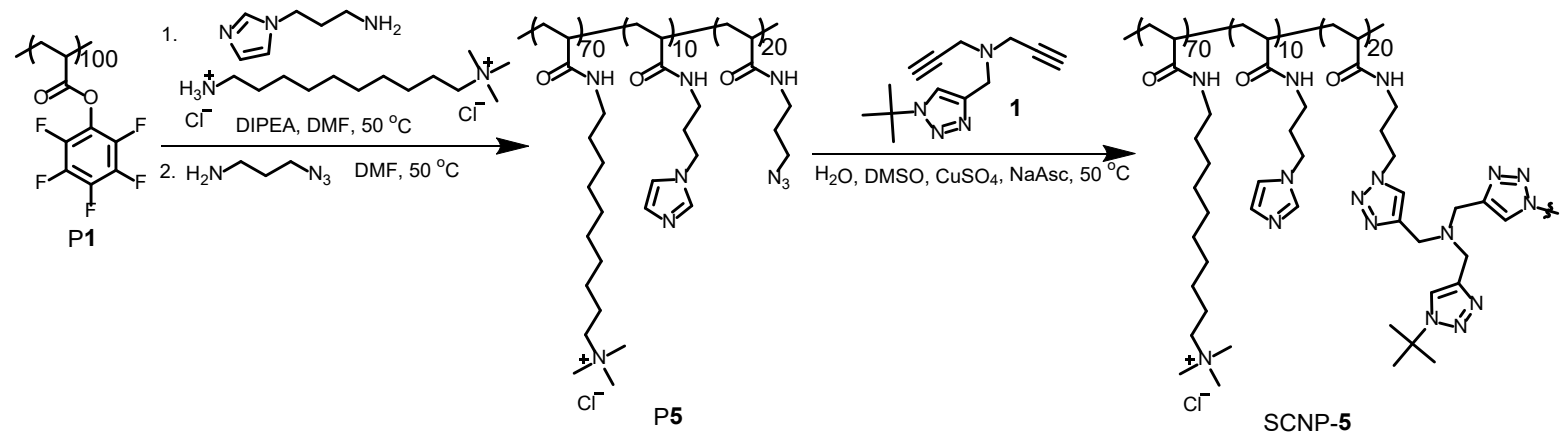

In a $20 \mathrm{~mL}$ screw-cap glass vial, $100 \mathrm{mg}(4.1 \mu \mathrm{mol})$ of P1, $83 \mathrm{mg}(289 \mu \mathrm{mol}, 0.7 \mathrm{eq})$ of mono(10-(14azaneyl)- $N, N, N$-trimethyldecan-1-aminium) dichloride and $5.4 \mathrm{mg}(41 \mu \mathrm{mol}, 0.1 \mathrm{eq})$ of 3-(1H-imidazol-1yl)propan-1-amine were dissolved in a mixture of $1 \mathrm{~mL}$ of DMF and $100 \mu \mathrm{L}$ of DIPEA. The vial was capped, sealed with parafilm, and stirred at $50{ }^{\circ} \mathrm{C}$ for $3 \mathrm{~h}$. To the mixture, $17 \mathrm{mg}$ (165 $\left.\mu \mathrm{mol}, 0.4 \mathrm{eq}\right)$ of 3 azidopropan-1-amine was added and stirred at $50{ }^{\circ} \mathrm{C}$ for another $3 \mathrm{~h}$. The mixture was cooled to room temperature and precipitated in $14 \mathrm{~mL}$ of ethyl ether in a $15 \mathrm{~mL}$ centrifuge tube. P5 was collected by centrifugation and the supernatant was discarded. The gel-like solid was redissolved in $1 \mathrm{~mL}$ of $\mathrm{MeOH}$ in the centrifuge tube and $14 \mathrm{~mL}$ of ethyl ether was added to precipitate P5. The precipitate was collected by centrifugation, and supernatant was discarded. This process was repeated twice. The resulting gel-like polymer was dissolved in $3 \mathrm{~mL}$ of water and purified by dialysis ( $1 \mathrm{kD}$ cut-off) with water for $16 \mathrm{~h}$. The resulting solution was lyophilized to afford P5 as a white powder.

In a $300 \mathrm{~mL}$ round bottom flask, $80 \mathrm{mg}(3.0 \mu \mathrm{mol})$ of $\mathrm{P} 5$ and $300 \mu \mathrm{L}$ of $100 \mathrm{mM}$ DMSO solution of 1 were dissolved in $60 \mathrm{~mL}$ of water. To the mixture, $60 \mu \mathrm{L}$ of $100 \mathrm{mM}$ aqueous solution of $\mathrm{CuSO}_{4}$ and $20 \mathrm{mg}$ of sodium ascorbate were added under $\mathrm{N}_{2}$ atmosphere. The mixture was stirred at $30{ }^{\circ} \mathrm{C}$ for $2 \mathrm{~h}$, and the temperature was raised to $50{ }^{\circ} \mathrm{C}$ and stirred overnight. Volatiles were removed using a rotary evaporator and the resulting SCNP-5 was dissolved in $3 \mathrm{~mL}$ of water. The SCNP-5 solution was added with $1 \mathrm{~g}$ of Chelex 100 chelating resin, and the mixture was gently shaken overnight to remove copper ions. The resin was removed by filtration. The SCNP-5 solution was purified by dialysis ( $1 \mathrm{kD}$ cut-off) with $1 \mathrm{M}$ aqueous solution of $\mathrm{NaCl}$ for $8 \mathrm{~h}$ and water for $48 \mathrm{~h}$. The resulting solution was lyophilized to afford SCNP-5 as a white powder. The conversion of each step is almost quantitative and the yield is typically range from $80-$ $90 \%$ due to losses during the purification.

\section{SCNP-6}

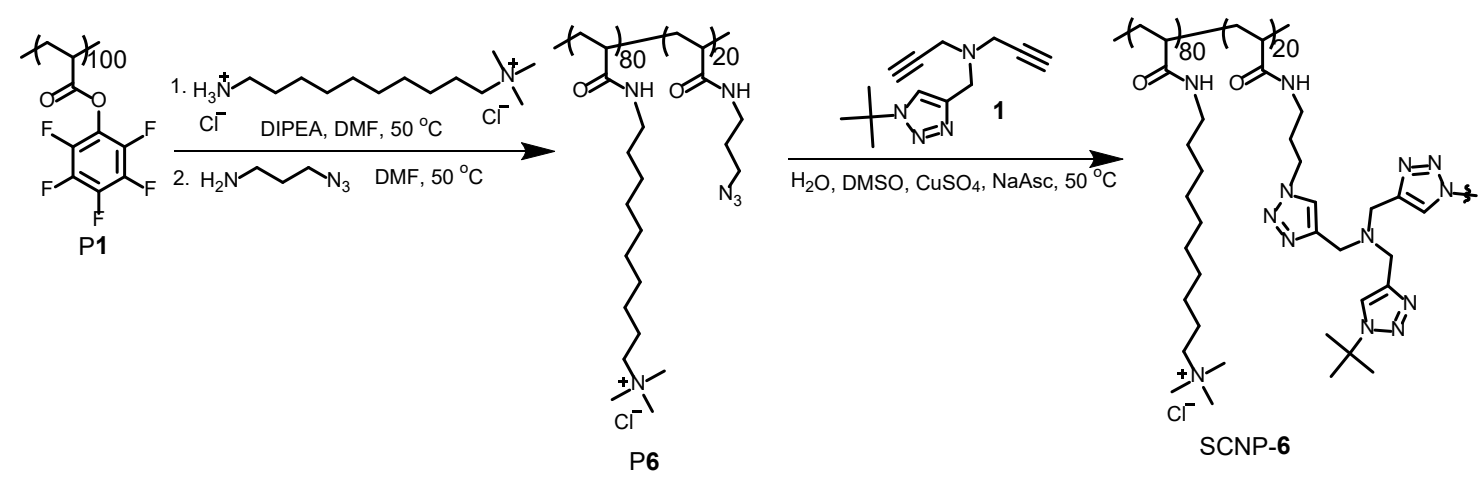


In a $20 \mathrm{~mL}$ screw-cap glass vial, $100 \mathrm{mg}(4.1 \mu \mathrm{mol})$ of P1 and $95 \mathrm{mg}$ (328 $\mu \mathrm{mol}, 0.8 \mathrm{eq})$ of mono(10-(14azaneyl)- $N, N, N$-trimethyldecan-1-aminium) dichloride were dissolved in a mixture of $1 \mathrm{~mL}$ of DMF and $100 \mu \mathrm{L}$ of DIPEA. The vial was capped, sealed with parafilm, and stirred at $50{ }^{\circ} \mathrm{C}$ for $3 \mathrm{~h}$. To the mixture, $17 \mathrm{mg}(165 \mu \mathrm{mol}, 0.4 \mathrm{eq})$ of 3-azidopropan-1-amine was added and stirred at $50{ }^{\circ} \mathrm{C}$ for another $3 \mathrm{~h}$. The mixture was cooled to room temperature and precipitated in $14 \mathrm{~mL}$ of ethyl ether in a $15 \mathrm{~mL}$ centrifuge tube. P6 was collected by centrifugation and the supernatant was discarded. The gel-like solid was redissolved in $1 \mathrm{~mL}$ of $\mathrm{MeOH}$ in the centrifuge tube and $14 \mathrm{~mL}$ of ethyl ether was added to precipitate $\mathrm{P6}$. The precipitate was collected by centrifugation and supernatant was discarded. This process was repeated twice. The resulting gel-like polymer was dissolved in $3 \mathrm{~mL}$ of water and purified by dialysis $(1 \mathrm{kD}$ cutoff) with water for $16 \mathrm{~h}$. The resulting solution was lyophilized to afford P6 as a white powder.

In a $300 \mathrm{~mL}$ round bottom flask, $83 \mathrm{mg}(3.0 \mu \mathrm{mol})$ of $\mathrm{P} 6$ and $300 \mu \mathrm{L}$ of $100 \mathrm{mM}$ DMSO solution of 1 were dissolved in $60 \mathrm{~mL}$ of water. To the mixture, $60 \mu \mathrm{L}$ of $100 \mathrm{mM}$ aqueous solution of $\mathrm{CuSO}_{4}$ and $20 \mathrm{mg}$ of sodium ascorbate $(20 \mathrm{mg}, 101 \mu \mathrm{mol})$ were added under $\mathrm{N}_{2}$ atmosphere. The mixture was stirred at $30{ }^{\circ} \mathrm{C}$ for $2 \mathrm{~h}$, and the temperature was raised to $50{ }^{\circ} \mathrm{C}$ and stirred overnight. Volatiles were removed using a rotary evaporator and the resulting SCNP-6 was dissolved in $3 \mathrm{~mL}$ of water. The SCNP-6 solution was added with $1 \mathrm{~g}$ of Chelex 100 chelating resin, and the mixture was gently shaken overnight to remove copper ions. The resin was removed by filtration. The SCNP-6 solution was purified by dialysis $(1 \mathrm{kD}$ cutoff) with $1 \mathrm{M}$ aqueous solution of $\mathrm{NaCl}$ for $8 \mathrm{~h}$ and water for $48 \mathrm{~h}$. The resulting solution was lyophilized

to afford SCNP-6 as a white powder. The conversion of each step is almost quantitative and the yield is typically range from $80-90 \%$ due to losses during the purification.

\section{Comparison of the crosslinking of P3 and P4.}

For comparing the crosslinking of $\mathrm{P} 3$ and $\mathrm{P} 4$, the reactions were conducted in $7 \mathrm{~mL}$ glass vials separately. For crosslinking P4, the reaction was performed with $\mathrm{P} 4(200 \mu \mathrm{M}), \mathbf{1}(4 \mathrm{mM}), \mathrm{CuSO}_{4}(1 \mathrm{mM})$ and sodium ascorbate $(2 \mathrm{mM})$ in $3 \mathrm{~mL}$ of water. For crosslinking P3, the reaction was performed with P3 $(200 \mu \mathrm{M}), \mathbf{1}$ $(4 \mathrm{mM}), \mathrm{CuSO}_{4}(1 \mathrm{mM})$ and sodium ascorbate $(2 \mathrm{mM})$ in $3 \mathrm{~mL}$ of a $9: 1(\mathrm{v} / \mathrm{v})$ mixture of ethanol and water. 
Both reactions were stirred at $50^{\circ} \mathrm{C}$ for $16 \mathrm{~h}$ under $\mathrm{N}_{2}$ and their images immediately taken after the reactions were shown in Figure S1.
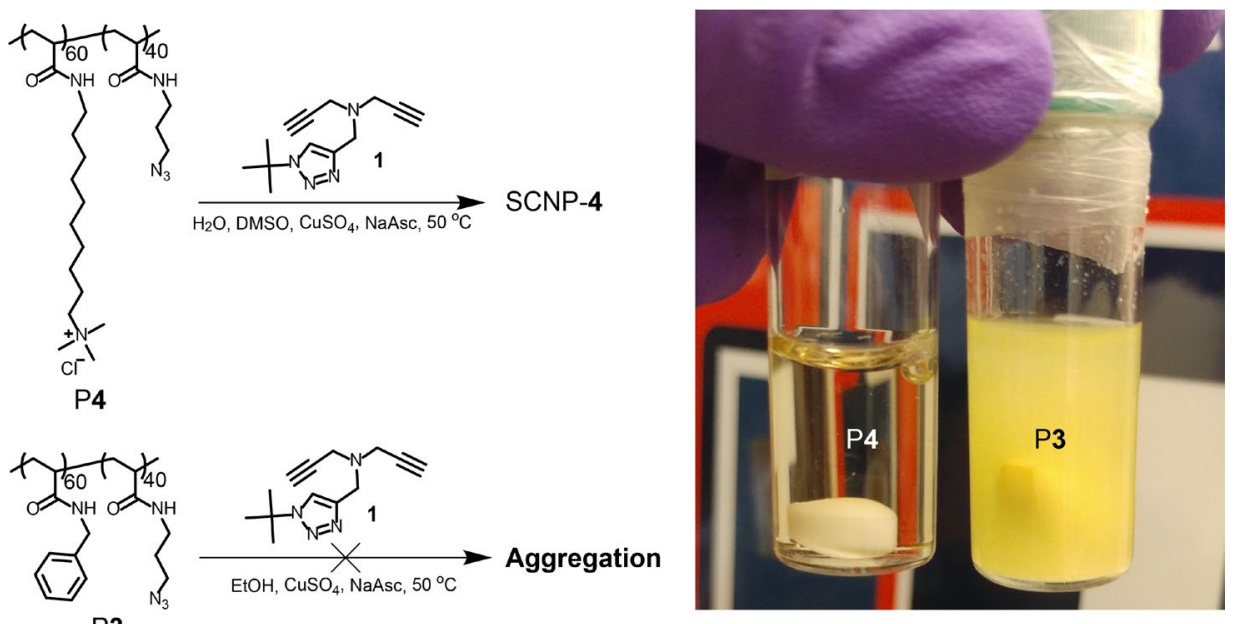

P3

Figure S1. Crosslinking reactions performed on P3 and P4 at $200 \mu \mathrm{M}$.

\section{Preparation of Cu'-SCNPs Solution}

The SCNP solutions were prepared in fresh Milli-Q water at $200 \mu \mathrm{M}$ in a $20 \mathrm{~mL}$ screw-cap glass vial, and $100 \mathrm{mM}$ aqueous solution of $\mathrm{CuSO}_{4}$ was added in 1:1 ratio between $\mathrm{Cu}$ and SCNP ligands. The average number of coordination ligands on each SCNP-2, SCNP-3, SCNP-5 and SCNP-6 is ten, and the final concentration of $\mathrm{Cu}$ ion will be $2 \mathrm{mM}$ for their $200 \mu \mathrm{M}$ solution. The average number of coordination ligands on each SCNP-4 is 20, and the final concentration of $\mathrm{Cu}$ ion will be $4 \mathrm{mM}$ for its $200 \mu \mathrm{M}$ solution. After adding the $\mathrm{CuSO}_{4}$ solution, the solution was stirred and shaken for a few second and used without further purification. 


\section{Synthetic Scale Reactions Catalyzed by SCNP-2.}

In a $3 \mathrm{~mL}$ vial, $1.0 \mathrm{mmol}$ of azido substrate, $1.2 \mathrm{mmol}$ of alkyne substrate and $20 \mathrm{nmol}$ of Cu${ }^{\text {II }}-\mathrm{SCNP}-2$ were mixed with $2 \mathrm{~mL}$ of water, and $10 \mathrm{mg}$ of sodium ascorbate was added under $\mathrm{N}_{2}$. The vial was sealed, and the mixture was stirred at $50{ }^{\circ} \mathrm{C}$ for $24 \mathrm{~h}$. After reaction, the aqueous solution was extracted 5 times with $1 \mathrm{~mL}$ of DCM. The combined organic layer was concentrated using a rotary evaporator, and the crude product was purified by column chromatography on silica (flash gel). The results are shown in Table S1.

Table S1. Small molecule synthesis catalyzed by $\mathrm{Cu}$ I-SCNP-2

Yield (\%)

a. Isolated yield.

b. $0.5 \mathrm{mmol}$ of azido substrate was added, since it contains two azido groups. 


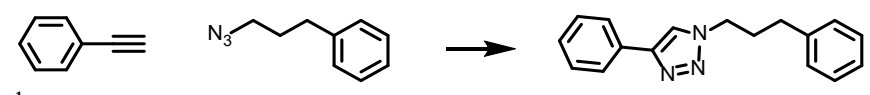

${ }^{1} \mathrm{H}$ NMR: $\delta 7.85(\mathrm{~d}, J=7.5,2 \mathrm{H}), 7.72(\mathrm{~s}, \mathrm{H}), 7.43(\mathrm{t}, J=7.4,2 \mathrm{H}), 7.31(\mathrm{~m}, 3 \mathrm{H}), 7.20(\mathrm{~m}, 3 \mathrm{H}), 4.39(\mathrm{t}, J=$ 7.1, 2H), $2.69(\mathrm{t}, J=7.3,2 \mathrm{H}), 2.30(\mathrm{~m}, 2 \mathrm{H}) .{ }^{13} \mathrm{C} \mathrm{NMR:}(125 \mathrm{MHz}): \delta 147.8,140.2,130.7,128.9,128.6$, $128.5,128.2,126.4,125.7,119.6,49.6,32.5,31.7$. High resolution ESI-MS: calculated for $\mathrm{C}_{17} \mathrm{H}_{18} \mathrm{~N}_{3}{ }^{+}$ $\left([\mathrm{M}+\mathrm{H}]^{+}\right): 264.1501$; found 264.1505 .

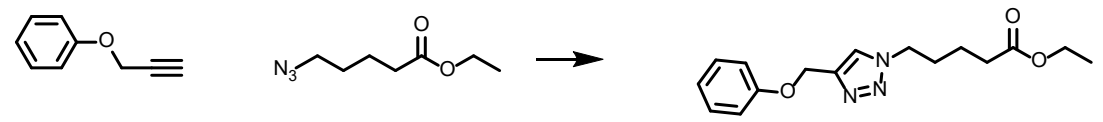

${ }^{1} \mathrm{H}$ NMR: $\delta 7.53(\mathrm{~s}, 1 \mathrm{H}), 7.21(\mathrm{t}, J=7.9,2 \mathrm{H}), 6.90(\mathrm{~m}, 3 \mathrm{H}), 5.13(\mathrm{~s}, 2 \mathrm{H}), 4.29(\mathrm{t}, J=7.2,2 \mathrm{H}), 4.05(\mathrm{q}, J=$ $7.1,2 \mathrm{H}), 2.26(\mathrm{t}, J=7.3,2 \mathrm{H}), 1.88(\mathrm{~m}, 2 \mathrm{H}), 1.58(\mathrm{~m}, 2 \mathrm{H}), 1.18(\mathrm{t}, J=7.2,3 \mathrm{H}) .{ }^{13} \mathrm{C}$ NMR: $(125 \mathrm{MHz}): \delta$ $172.9,158.2,144.3,129.5,122.5,121.2,114.8,62.0,60.5,50.0,33.4,29.6,21.8,14.2$. High resolution ESI-MS: calculated for $\mathrm{C}_{16} \mathrm{H}_{22} \mathrm{~N}_{3} \mathrm{O}_{3}{ }^{+}\left([\mathrm{M}+\mathrm{H}]^{+}\right)$: 304.1661; found 304.1648.

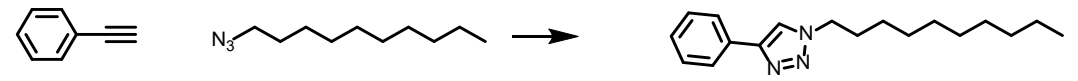

${ }^{1} \mathrm{H}$ NMR: $\delta 7.84(\mathrm{~d}, J=7.1,2 \mathrm{H}), 7.76(\mathrm{~s}, 1 \mathrm{H}), 7.43(\mathrm{t}, J=7.4,2 \mathrm{H}), 7.34(\mathrm{t}, J=7.4,1 \mathrm{H}), 4.39(\mathrm{t}, J=7.2$, $2 \mathrm{H}), 1.95(\mathrm{~m}, 2 \mathrm{H}), 1.27(\mathrm{~m}, 14 \mathrm{H}), 0.89(\mathrm{t}, J=6.9,3 \mathrm{H}) .{ }^{13} \mathrm{C}$ NMR: $(125 \mathrm{MHz}): \delta 147.6,130.8,128.8,128.0$, 125.7, 119.4, 50.4, 31.8, 30.4, 29.5, 29.4, 29.3, 29.0, 26.5, 22.7, 14.1. High resolution ESI-MS: calculated for $\mathrm{C}_{18} \mathrm{H}_{28} \mathrm{~N}_{3}^{+}\left([\mathrm{M}+\mathrm{H}]^{+}\right): 286.2283$; found 286.2271 .

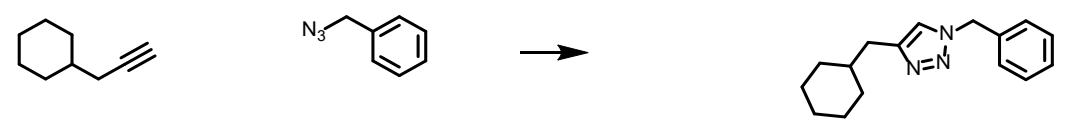

${ }^{1} \mathrm{H}$ NMR: $\delta 7.37(\mathrm{~m}, 3 \mathrm{H}), 7.27(\mathrm{~d}, J=7.1,2 \mathrm{H}), 7.18(\mathrm{~s}, 1 \mathrm{H}), 7.34(\mathrm{t}, J=7.4,1 \mathrm{H}), 5.51(\mathrm{~s}, 2 \mathrm{H}), 2.57(\mathrm{~d}, J=$ 7.0, 2H), 1.69 (m, 6H), $1.21(\mathrm{~m}, 3 \mathrm{H}), 0.96$ (m, 2H). ${ }^{13} \mathrm{C}$ NMR: (125 MHz): $\delta$ 147.5, 135.1, 129.1, 128.6, $127.9,121.1,53.9,38.1,33.5,33.1,26.4,26.2$. High resolution ESI-MS: calculated for $\mathrm{C}_{16} \mathrm{H}_{22} \mathrm{~N}_{3}{ }^{+}\left([\mathrm{M}+\mathrm{H}]^{+}\right)$: 256.1814; found 256.1806 .

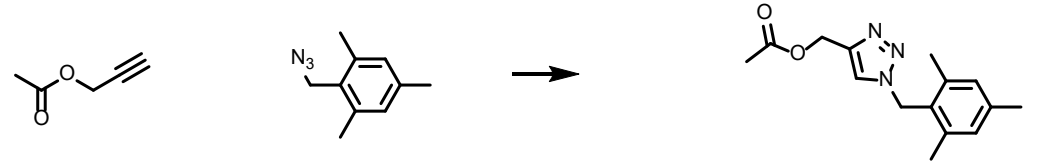

${ }^{1} \mathrm{H}$ NMR: $\delta 7.22(\mathrm{~s}, 1 \mathrm{H}), 6.95$ (s, 2H), 5.57 (s, 2H), 5.15 (s, 2H), 2.32 (s, 9H), 2.06 (s, 2H). ${ }^{13} \mathrm{C}$ NMR: (125 MHz): $\delta$ 170.8, 142.6, 139.1, 137.8, 129.7, 127.1, 122.6, 57.6, 48.3, 21.0, 21.2, 19.7. High resolution ESIMS: calculated for $\mathrm{C}_{15} \mathrm{H}_{20} \mathrm{~N}_{3} \mathrm{O}_{2}^{+}\left([\mathrm{M}+\mathrm{H}]^{+}\right)$: 274.1556; found 274.1567 .

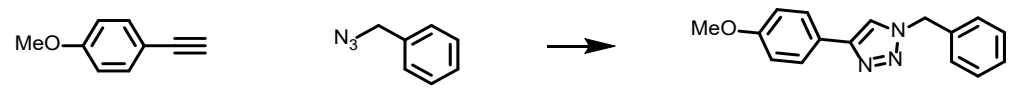

${ }^{1} \mathrm{H}$ NMR: $\delta 7.63(\mathrm{~d}, J=8.9,2 \mathrm{H}), 7.50(\mathrm{~s}, 1 \mathrm{H}), 7.29(\mathrm{~m}, 5 \mathrm{H}), 6.86(\mathrm{~d}, J=8.9,2 \mathrm{H}), 5.48(\mathrm{~s}, 2 \mathrm{H}), 3.75(\mathrm{~s}$, $3 \mathrm{H}) .{ }^{13} \mathrm{C}$ NMR: (125 MHz): $\delta$ 159.6, 148.1, 134.8, 129.1, 128.7, 128.0, 127.0, 123.3, 118.7, 114.2, 55.3, 54.2. High resolution ESI-MS: calculated for $\mathrm{C}_{16} \mathrm{H}_{16} \mathrm{~N}_{3} \mathrm{O}^{+}\left([\mathrm{M}+\mathrm{H}]^{+}\right)$: 266.1293; found 266.1302 . 


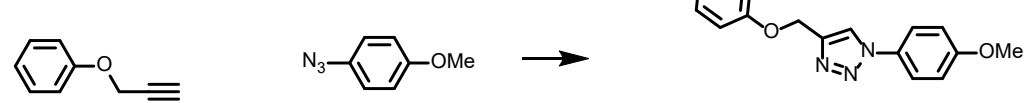

${ }^{1} \mathrm{H}$ NMR: $\delta .99(\mathrm{~s}, 1 \mathrm{H}), 7.66(\mathrm{~d}, J=8.9,2 \mathrm{H}), 7.33(\mathrm{t}, J=7.7,2 \mathrm{H}), 7.04(\mathrm{~m}, 5 \mathrm{H}), 5.31(\mathrm{~s}, 2 \mathrm{H}), 3.88(\mathrm{~s}, 3 \mathrm{H})$. ${ }^{13} \mathrm{C}$ NMR: (125 MHz): $\delta$ 159.9, 158.2, 144.8, 130.5, 129.6, 122.3, 121.3, 121.1, 114.8, 62.0, 55.6. High resolution ESI-MS: calculated for $\mathrm{C}_{16} \mathrm{H}_{16} \mathrm{~N}_{3} \mathrm{O}_{2}^{+}\left([\mathrm{M}+\mathrm{H}]^{+}\right)$: 282.1243; found 282.1242.
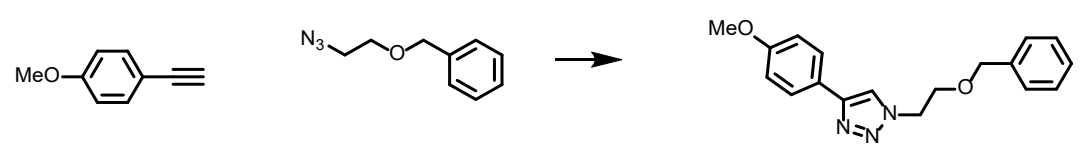

${ }^{1} \mathrm{H}$ NMR: $\delta 7.83(\mathrm{~s}, 1 \mathrm{H}), 7.77(\mathrm{~d}, J=7.2,2 \mathrm{H}), 7.32(\mathrm{~m}, 5 \mathrm{H}), 6.99(\mathrm{~d}, J=8.3,2 \mathrm{H}), 4.61(\mathrm{t}, J=4.7,2 \mathrm{H}), 4.54$ (s, 2H), 3.9 (t, $J=4.7,2 \mathrm{H}), 3.87(\mathrm{~s}, 3 \mathrm{H}) .{ }^{13} \mathrm{C}$ NMR: $(125 \mathrm{MHz}): \delta 159.5,147.6,137.4,128.6,128.0,127.8$, 127.0, 123.5, 120.0, 114.2, 73.5, 68.5, 55.3, 50.5. High resolution ESI-MS: calculated for $\mathrm{C}_{18} \mathrm{H}_{20} \mathrm{~N}_{3} \mathrm{O}_{2}{ }^{+}$ $\left([\mathrm{M}+\mathrm{H}]^{+}\right): 310.1556$; found 310.1563 .

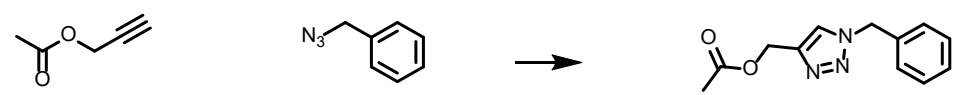

${ }^{1} \mathrm{H}$ NMR: $\delta 7.53(\mathrm{~s}, 1 \mathrm{H}), 7.38(\mathrm{~m}, 3 \mathrm{H}), 7.29$ (d, $\left.J=7.3,2 \mathrm{H}\right), 5.54(\mathrm{~s}, 2 \mathrm{H}), 5.19(\mathrm{~s}, 2 \mathrm{H}), 2.07$ (s, 3H). ${ }^{13} \mathrm{C}$ NMR: (125 MHz): $\delta 170.8,143.3,134.4,129.2,128.9,128.2,123.5,57.6,54.2,20.9$. High resolution ESIMS: calculated for $\mathrm{C}_{12} \mathrm{H}_{14} \mathrm{~N}_{3} \mathrm{O}_{2}^{+}\left([\mathrm{M}+\mathrm{H}]^{+}\right)$: 232.1086; found 232.1090.

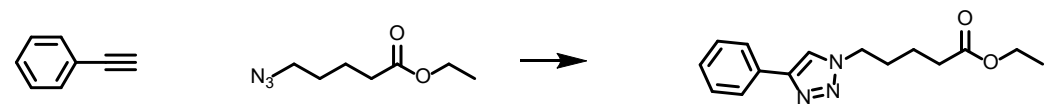

${ }^{1} \mathrm{H}$ NMR: $\delta 7.76(\mathrm{~d}, J=7.2,2 \mathrm{H}), 7.69(\mathrm{~s}, 1 \mathrm{H}), 7.34(\mathrm{t}, J=7.4,2 \mathrm{H}), 7.25(\mathrm{t}, J=7.3,1 \mathrm{H}), 4.34(\mathrm{t}, J=7.1$, $2 \mathrm{H}), 4.04(\mathrm{q}, J=7.1,2 \mathrm{H}), 2.28(\mathrm{t}, J=7.3,2 \mathrm{H}), 1.93(\mathrm{~m}, 2 \mathrm{H}), 1.62(\mathrm{~m}, 2 \mathrm{H}), 1.17(\mathrm{t}, J=7.2,3 \mathrm{H}) .{ }^{13} \mathrm{C} \mathrm{NMR}$ : (125 MHz): $\delta 172.9,147.8,130.7,128.8,128.1,125.7,119.5,60.5,50.0,33.4,29.7,21.8$, 14.2. High resolution ESI-MS: calculated for $\mathrm{C}_{15} \mathrm{H}_{20} \mathrm{~N}_{3} \mathrm{O}_{2}^{+}\left([\mathrm{M}+\mathrm{H}]^{+}\right)$: 274.1556; found 274.1547.

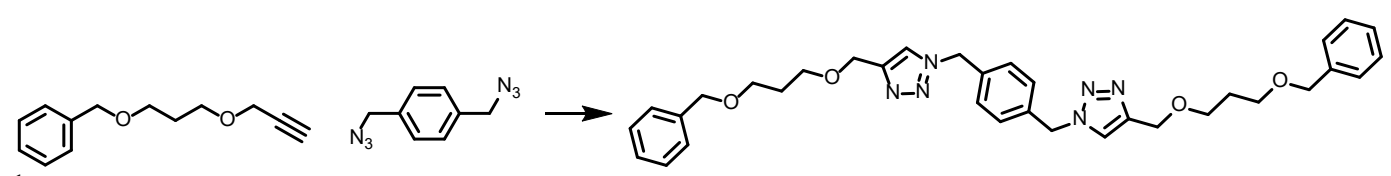

${ }^{1} \mathrm{H}$ NMR: $\delta 7.43(\mathrm{~s}, 2 \mathrm{H}), 7.30(\mathrm{~m}, 14 \mathrm{H}), 5.44(\mathrm{~s}, 4 \mathrm{H}), 4.58(\mathrm{~s}, 4 \mathrm{H}), 4.46(\mathrm{~s}, 4 \mathrm{H}), 3.62(\mathrm{t}, J=6.4,4 \mathrm{H}), 3.54$ $(\mathrm{t}, J=6.3,4 \mathrm{H}), 1.89(\mathrm{~m}, 4 \mathrm{H}) .{ }^{13} \mathrm{C}$ NMR: $(125 \mathrm{MHz}): \delta 145.9,138.5,135.3,128.7,128.4,127.6,127.5$, $122.4,72.9,67.8,67.2,64.4,53.5,30.0$. High resolution ESI-MS: calculated for $\mathrm{C}_{34} \mathrm{H}_{41} \mathrm{~N}_{6} \mathrm{O}_{4}{ }^{+}\left([\mathrm{M}+\mathrm{H}]^{+}\right)$: 597.3189; found 597.3190. 


\section{Polymer Characterization}

\section{Transmission electron microscopy (TEM)}

A $2 \mu \mathrm{M}$ solution of SCNP in fresh Milli-Q water $(8 \mu \mathrm{L})$ was applied to a UC-A on lacey gold TEM grid (Ted Pella) for $20 \mathrm{~min}$. The SCNP solution was carefully removed by using a filter paper to absorb the solution. Ammonium molybdate ( $2 \mathrm{wt} \%$ in water, $8 \mu \mathrm{L}$ ) was added to the grid surface to negatively stain the SCNP. The staining process was conducted for $20 \mathrm{~min}$ and the solution was removed using filter paper. The TEM grid was allowed to air dry for $1 \mathrm{~h}$. The TEM imaging was performed on a JEOL 2100 Cryo TEM with $200 \mathrm{keV}$, and the images were processed using ImageJ.

\section{Atomic force microscopy (AFM)}

A $2 \mu \mathrm{M}$ solution of SCNP in fresh Milli-Q water $(20 \mu \mathrm{L})$ was spin-coated onto a $1 \mathrm{~cm} \times 1 \mathrm{~cm}$ plasm sputtered silicon wafer at $2000 \mathrm{rpm}$ for $3 \mathrm{~min}$. The nanoparticle coated silicon wafers were imaged using a multimode nanoScope IIIa AFM microscope.

\section{Dynamic Light Scattering and Zeta Potential}

The SCNP solution was prepared in fresh Milli-Q water at $25 \mu \mathrm{M}$. The solution was transferred to a disposable $4 \mathrm{~mL}$ plastic vial for the DLS instrument and sonicated for around $30 \mathrm{~s}$ before the measurement. The light scattering data was subsequently measured by using a Marvin Instrument Ltd. nanoZS Zetasizer.

\section{Relaxation Time $\mathbf{T}_{2}$ Determination and DOSY Experiment}

The NMR solutions of P4 $(100 \mu \mathrm{M})$ and SCNP-4 $(100 \mu \mathrm{M})$ in $\mathrm{D}_{2} \mathrm{O}$ or DMSO-d6 were prepared respectively, and the NMR experiments of the four solutions were conducted independently. Proton spin-spin relaxation time $\mathrm{T}_{2}$ was determined by using Carr-Purchell-Meiboom-Gill pulse sequence on a VNS750 spectrometer. The data was processed by MestreNova 8.1, and the peak integrations of the trimethyl ammonium group $(3.0 \mathrm{ppm})$ and hydrophobic allyl chains $(1.2 \mathrm{ppm})$ were fitted to a mono-exponential function: $\mathrm{M}_{\mathrm{xy}}(\mathrm{t})=$ $\mathrm{M}_{\mathrm{xy}}(0) \mathrm{e}^{-\mathrm{t} / \mathrm{T} 2}$ to calculate $\mathrm{T}_{2}$. Diffusion ordered spectroscopy (DOSY) experiments were performed on a VNS750 spectrometer through the pulse sequence that encodes the Z-gradient amplifier capability. The diffusion coefficients were calculated from Stejskal-Tanner function. Hydrodynamic diameters were calculated from Stokes-Einstein equation. 
a

\begin{tabular}{|l|c|c|c|c|} 
& $\begin{array}{c}\mathrm{P} 2 \\
\mathrm{D}_{2} \mathrm{O}\end{array}$ & $\begin{array}{c}\text { SCNP-2 } \\
\mathrm{D}_{2} \mathrm{O}\end{array}$ & $\begin{array}{c}\mathrm{P} 2 \\
\text { DMSO-d6 }\end{array}$ & $\begin{array}{c}\text { SCNP-2 } \\
\text { DMSO-d6 }\end{array}$ \\
\hline $\mathrm{T}_{2}-\mathrm{N}\left(\mathrm{CH}_{3}\right)_{3}$ (ms) & 239 & 81.7 & 118 & 42.8 \\
\hline $\mathrm{T}_{2}-\left(\mathrm{CH}_{2}\right)_{6}$ (ms) & 39.2 & 16.4 & 30.9 & 11.2 \\
\hline
\end{tabular}

b

\begin{tabular}{|c|c|c|}
\hline ICP Analysis Objects & Cu lons Per SCNP & Theoretical Amount \\
\hline SCNP-2 without adding Cu & 0.098 & 0 \\
\hline Cull-SCNP-2 & 10.3 & 10 \\
\hline
\end{tabular}
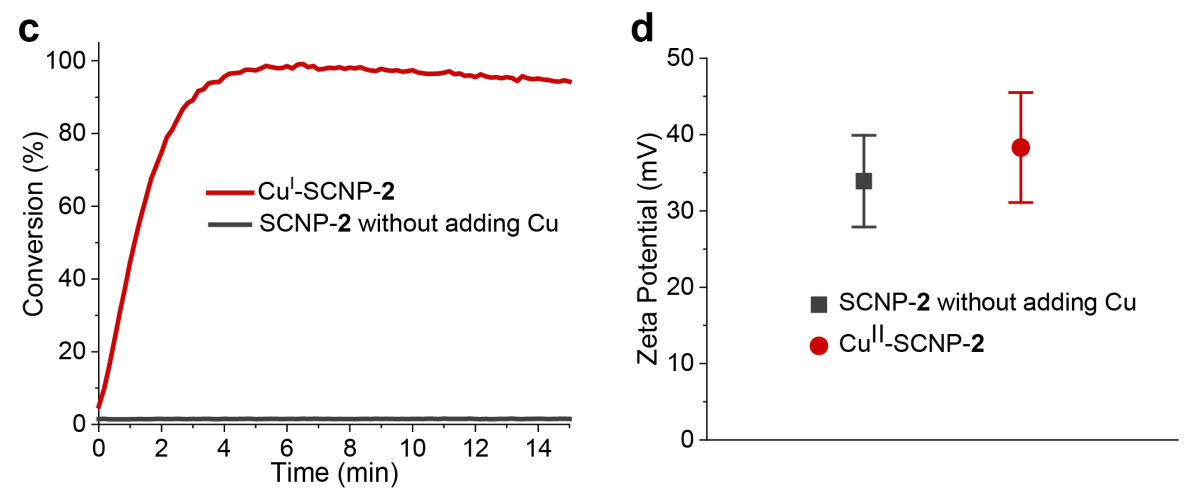

Figure S2. a, proton relaxation time $\mathrm{T}_{2}$ of P2 and SCNP-2 in $\mathrm{D}_{2} \mathrm{O}$ or DMSO-d6 at $100 \mu \mathrm{M}$ measured by NMR. $\mathbf{b}$, the average number of $\mathrm{Cu}$ ions per nanoparticle determined by ICP analysis. $\mathbf{c}$, kinetics comparison of the fluorogenic reactions between SCNP-2 before and after adding $\mathrm{CuSO}_{4}$. Reactions were conducted in PBS buffer $(1 \mathrm{x}, \mathrm{pH}=7.4)$ at room temperature with SCNP-2 $(2 \mu \mathrm{M}), 2(20 \mu \mathrm{M}), \mathbf{3 a}$ $(40 \mu \mathrm{M})$ and sodium ascorbate $(2 \mathrm{mM})$. d, zeta potential of SCNP-2 before and after adding $\mathrm{Cu}$ measured by a zetasizer. 

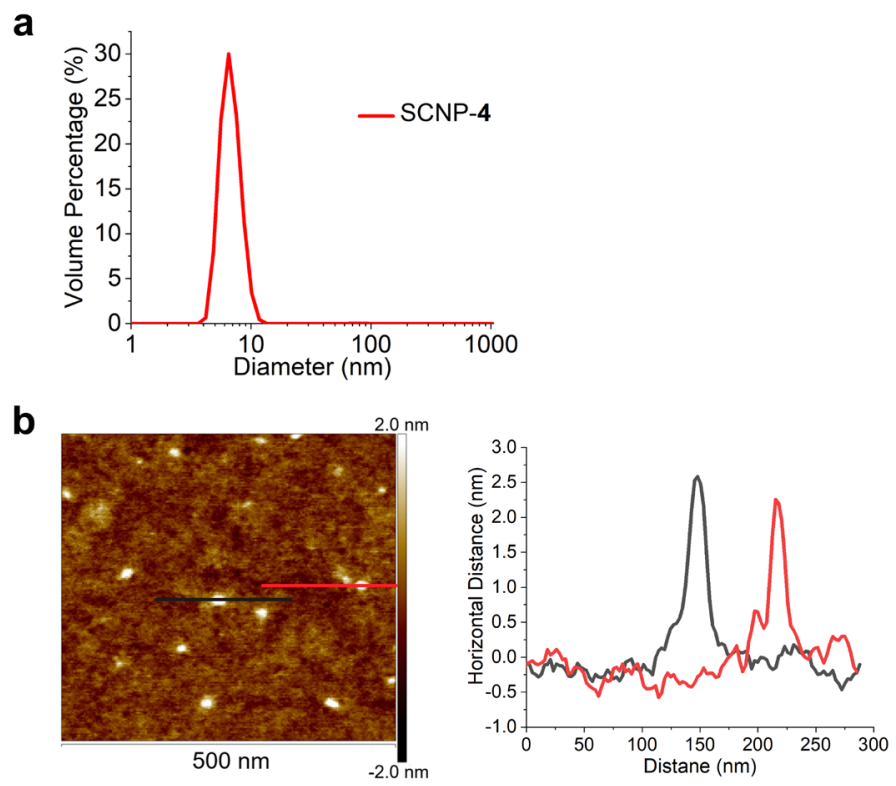

C

\begin{tabular}{|l|c|c|c|c|} 
& $\mathrm{P} 4$ & SCNP-4 & P4 & SCNP-4 \\
& $\mathrm{D}_{2} \mathrm{O}$ & $\mathrm{D}_{2} \mathrm{O}$ & DMSO-d6 & DMSO-d6 \\
\hline $\mathrm{T}_{2}-\mathrm{N}\left(\mathrm{CH}_{3}\right)_{3}(\mathrm{~ms})$ & 294 & 25.3 & 145 & 55.4 \\
$\mathrm{~T}_{2}-\left(\mathrm{CH}_{2}\right)_{6} \quad(\mathrm{~ms})$ & 48.7 & 9.90 & 31.6 & 12.3 \\
Diameter $(\mathrm{nm})$ & 5.9 & 6.3 & 7.8 & 6.6 \\
\hline
\end{tabular}

Figure S3. a, DLS graph of SCNP-4 in water at $25 \mu \mathrm{M}$. b, the AFM image of SCNP-4 on silicon wafer. c, proton relaxation time $\mathrm{T}_{2}$ of $\mathrm{P} 4$ and SCNP-4 in $\mathrm{D}_{2} \mathrm{O}$ or DMSO-d6 measured by NMR, and hydrodynamic diameters measured by DOSY. 


\section{Click Catalysis with Small Molecules}

\section{Recyclability}

The CuAAC click reaction was performed in a $0.7-\mathrm{mL}$ fluorimeter cuvette. In $0.5 \mathrm{~mL}$ total volume of PBS buffer $(1 \mathrm{x}, \mathrm{pH}=7.4), \mathrm{Cu}^{\mathrm{II}}$-SCNP-2 was dissolved to reach a concentration of $2 \mu \mathrm{M}$. DMSO stock solutions of $\mathbf{2}$ and $\mathbf{3 a}$ were added to give a final concentration of $\mathbf{2}(20 \mu \mathrm{M}), \mathbf{3 a}(40 \mu \mathrm{M}),[\mathrm{NaAsc}]=2$ $\mathrm{mM}$ and $2 \%(\mathrm{v} / \mathrm{v})$ of DMSO. The rate of the click reaction was monitored by using a fluorometer for 15 min. The solution was transferred to an Amicon tube with $10 \mathrm{kDa}$ cutoff and the small molecules were removed by washing the solution with water. The polymer solution was concentrated and diluted with PBS buffer to perform the above catalysis reaction under same conditions, and the reaction was again monitored by using a fluorometer.

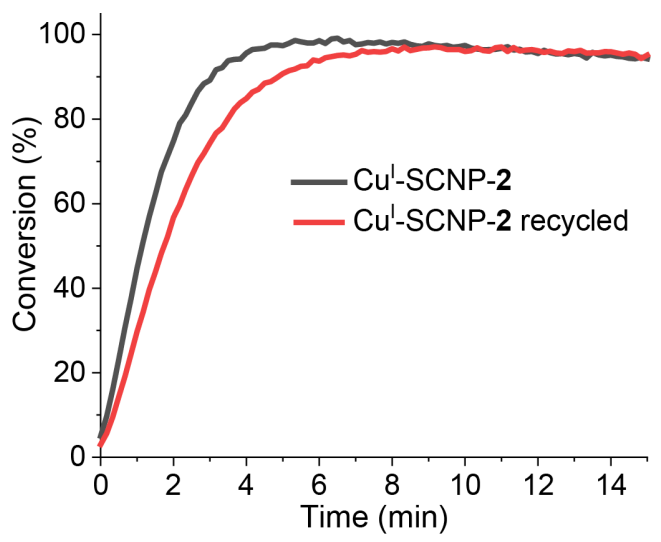

Figure S4. Kinetics comparison between $\mathrm{Cu}^{\mathrm{I}}-\mathrm{SCNPs}(2 \mu \mathrm{M})$ before and after the recycling. 


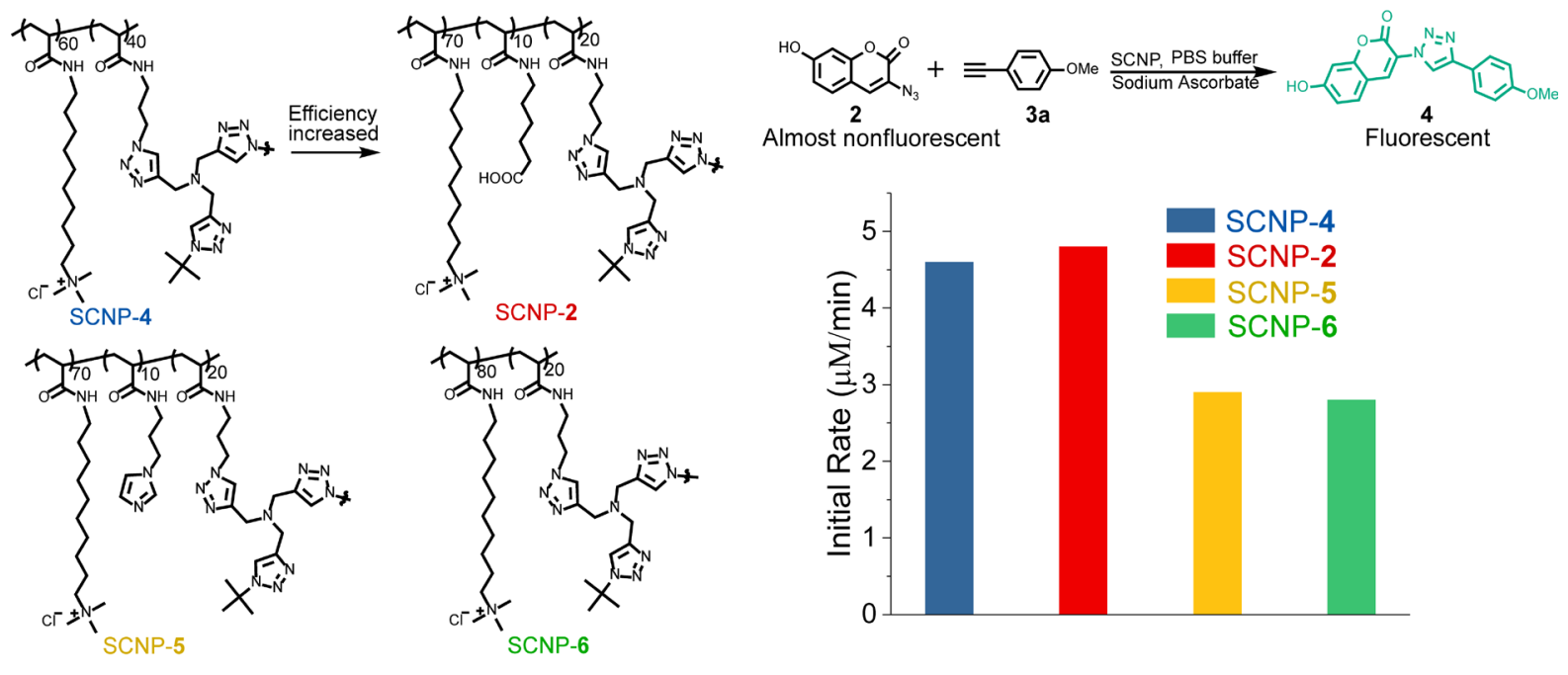

Figure S5. Kinetics comparison between different SCNPs. Reactions were conducted in PBS buffer $(1 \mathrm{x}, \mathrm{pH}=7.4)$ at room temperature with $\mathrm{Cu}^{\mathrm{I}}$-SCNPs $(1 \mu \mathrm{M}), \mathbf{2}(20 \mu \mathrm{M}), \mathbf{3 a}(40 \mu \mathrm{M})$ and sodium ascorbate $(2 \mathrm{mM})$. 

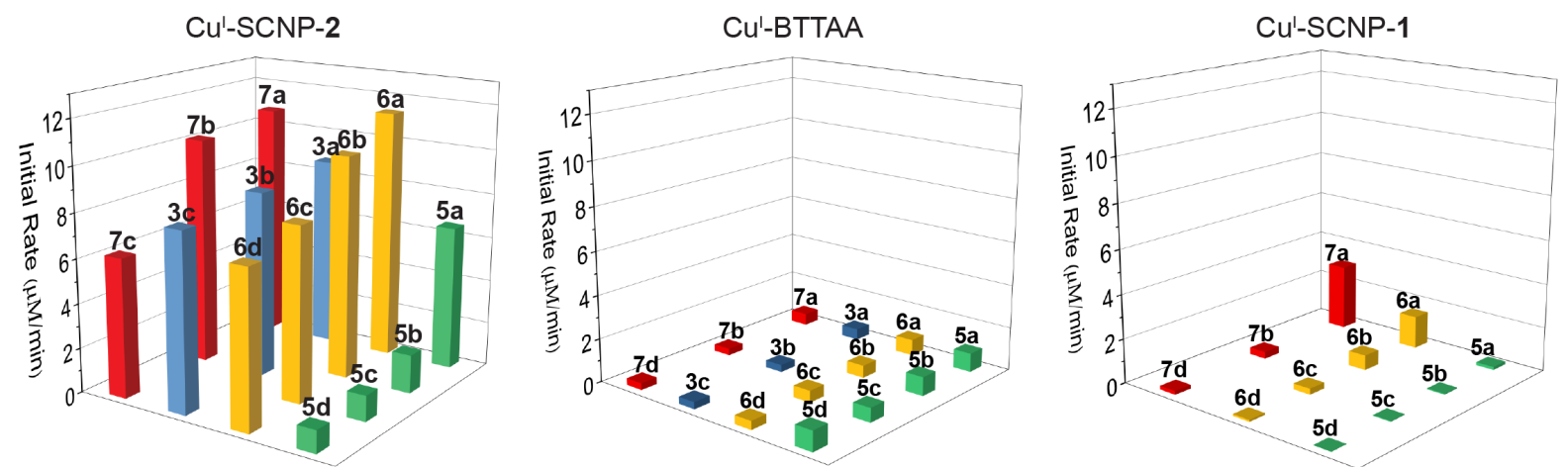

Figure S6. Initial reaction rates determined by fluorimeter with $\mathrm{Cu}^{\mathrm{I}}-\mathrm{SCNP}-2(2 \mu \mathrm{M})$ or $\mathrm{Cu}^{\mathrm{I}}-\mathrm{BTTAA}$ $(20 \mu \mathrm{M}), 2(20 \mu \mathrm{M})$, alkyne $(40 \mu \mathrm{M})$, and sodium ascorbate $(2 \mathrm{mM})$ in PBS buffer $(1 \mathrm{x}, \mathrm{pH}=7.4)$ at room temperature. The data for $\mathrm{Cu}^{\mathrm{I}}-\mathrm{SCNP}-1$ was adapted from our previous paper. ${ }^{2}$

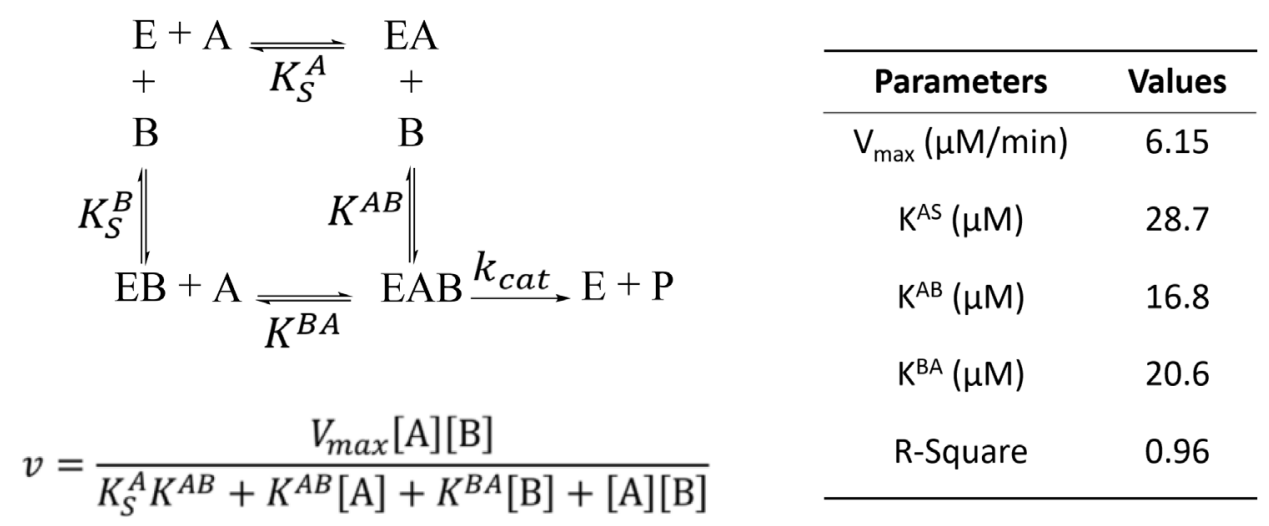

Figure S7. The fitting equation and parameters for random-sequential two substrates Bi-Bi enzyme kinetics equation fitting of $\mathrm{Cu}^{\mathrm{I}}-\mathrm{SCNP}-2$ kinetics data. 


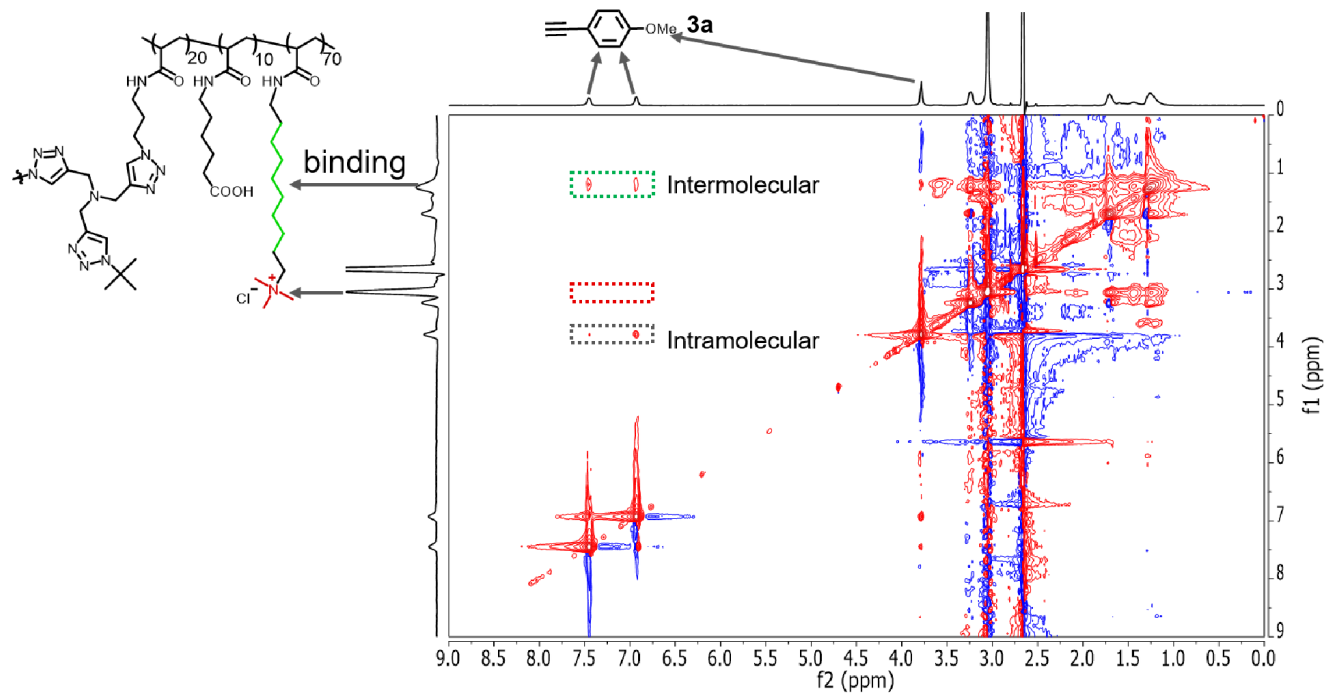

b

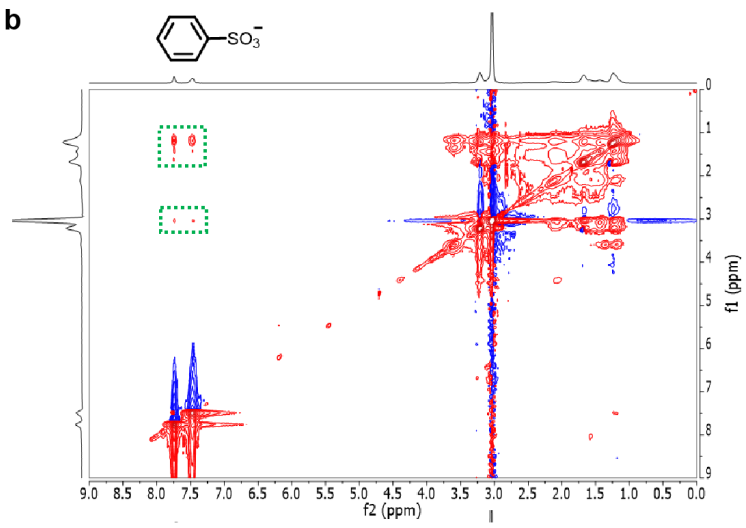

C

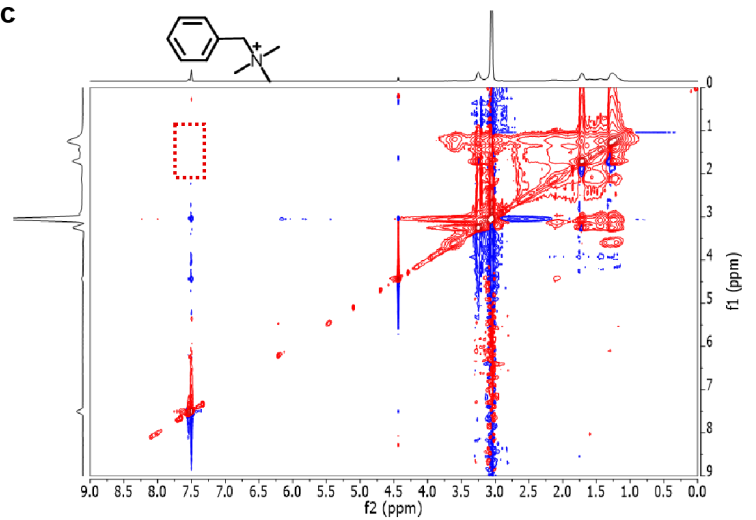

Figure S8. a, 2D-NOESY spectrum of $\mathrm{Cu}^{\mathrm{II}}-\mathrm{SCNP}-2(100 \mu \mathrm{M})$ and 3a $(3 \mathrm{mM})$ in $\mathrm{D}_{2} \mathrm{O}$. b, 2D-NOESY spectrum of $\mathrm{Cu}^{\mathrm{II}}$-SCNP-2 $(100 \mu \mathrm{M})$ and sodium benzenesulfonate $(3 \mathrm{mM})$ in $\mathrm{D}_{2} \mathrm{O}$. c, 2D-NOESY spectrum of Cu${ }^{\mathrm{II}}-\mathrm{SCNP}-2(100$ $\mu \mathrm{M})$ and benzyl trimethylammonium chloride $(3 \mathrm{mM})$ in $\mathrm{D}_{2} \mathrm{O}$. 


\section{$\underline{\text { MD Simulations }}$}

\section{Creating Molecular Models.}

All-atom molecular topologies and optimized geometries of the small molecules were generated using the freely available Automated Topology Builder (ATB) (http://atb.uq.edu.au). ${ }^{3}$ Optimized geometries were constructed by steepest descent energy minimization. Bonded and van der Waals terms of the molecular topology were modeled using the GROMOS 54A7 force field, ${ }^{4}$ and partial charges assigned by semiempirical quantum mechanical calculations conducted using the MOPAC method. ${ }^{5}$

Scheme S1. Chemical structure of the simulated SCNP-2. The polymer was divided in to five building components including $\mathrm{A}, \mathrm{B}, \mathrm{C}, \mathrm{C}$ ' and $\mathrm{D}$.
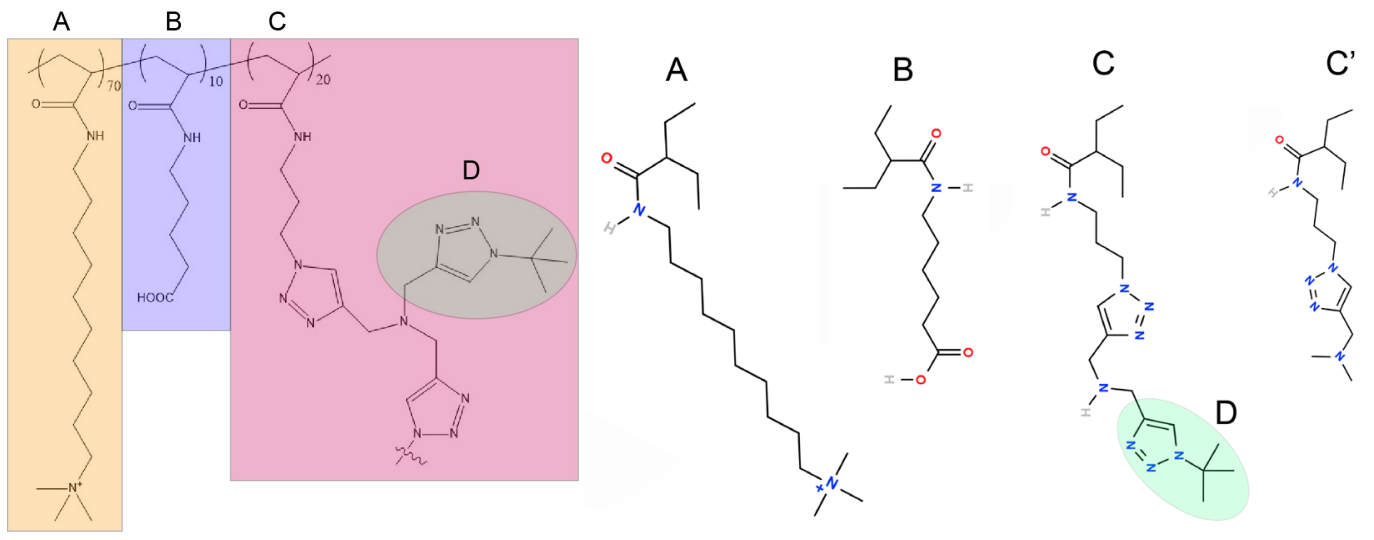

Scheme S2. Monomer sequence and crosslinking pairs on the simulated SCNP-2 molecule.

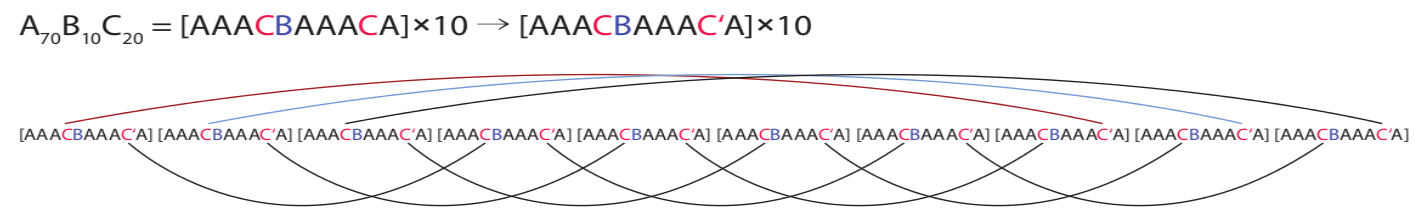

Polymer particle of SCNP-2 is created by combining small fragments, each fragment is generated using ATB the same as small molecules. The polymer chain can be decomposed into three types of elements A, B, C as shown in Scheme S1. However, type C are not symmetric to each other: two type $\mathrm{C}$ elements are combined and share one piece of fragment $\mathrm{D}$, we then divide $\mathrm{C}$ into two different types further as $\mathrm{C}$ and $\mathrm{C}$ ', where $\mathrm{C}$ include the shared fragment $\mathrm{D}$ and is larger than $\mathrm{C}^{\prime}$, and each pair of $\mathrm{C}$ and $\mathrm{C}^{\prime}$ are combined to each other during the cross-linking. Thus, four types of polymer elements are generated using ATB. Since the sequence of the polymer chain can be arbitrary, there is no deterministic sequence for the polymer, so we designed a typical sequence for doing molecular simulation, the sequence we designed tries to mix all four types of elements evenly to maximize the entropy and likelihood for the sequence. The designed sequence for the chain is shown in Scheme S2, the polymer chain is composed of 10 identical repeating segments, and each segment contains the elements in the order of [AAACBAAAC'A]. C' element in the ith segment is cross-linked to the $\mathrm{C}$ element in the ( $\mathrm{i}+3)$-th segment, where $\mathrm{i}=1,2, \ldots, 10$ indicates the index of the segments, when $i>7$, periodic boundary condition is imposed, so the 8-th segment is connecting to 
the 1-st segment, etc. We first link all the elements and segments into a stretched polymer chain by adding covalent bonds and modifying the corresponding topology files, then two stages of molecular simulation are conducted to generate the final cross-linked and folded polymer particle. In the first stage, the atoms in the corresponding C-C' pairs are slowly pulled close to each other, during which, the stretched polymer chain folds, when the corresponding C-C' element are close to each other, a covalent bond is added to link them to each other. After repeat these 10 times for $10 \mathrm{C}-\mathrm{C}$ ' pairs, the polymer chain folds into an almost globular state. Then, in the second stage, cross-linked polymer particle is simulated in water for $10 \mathrm{~ns}$, so that the particle further folds into a more relaxed configuration.

\section{Small Molecule Binding}

Molecular dynamics simulations were performed in GROMACS 4.6. ${ }^{6,7}$ Lennard-Jones interactions were shifted smoothly to zero at $1.4 \mathrm{~nm}$, and dispersion interactions between unlike atoms specified by LorentzBerthelot combining rules. ${ }^{8}$ Coulomb interactions were treated by Particle Mesh Ewald (PME) with a realspace cutoff of $1.4 \mathrm{~nm}$ and a $0.12 \mathrm{~nm}$ reciprocal-space grid spacing. ${ }^{9}$ Bond lengths were fixed to their equilibrium values using the LINCS algorithm. ${ }^{10}$ SPC water molecules is used as the solvent for each simulation. Temperature was maintained at $300 \mathrm{~K}$ using a Nosé-Hoover thermostat ${ }^{1}$ and pressure at 1.0 bar using an isotropic Parrinello-Rahman barostat ${ }^{12}$. Newton's equations of motion were integrated using the leap-frog algorithm ${ }^{13}$ with time step of 2 fs. Simulations for different small molecules were conducted independently with the same initial folded polymer sphere and random distributed small molecules in a box with the size of $10 \times 10 \times 10 \mathrm{~nm}^{3}$. Each simulation lasts for $20 \mathrm{~ns}$, and the analysis is performed using the last $10 \mathrm{~ns}$. The numbers of each substrate molecule inside the simulated SCNP-2 are shown in Figure S7.

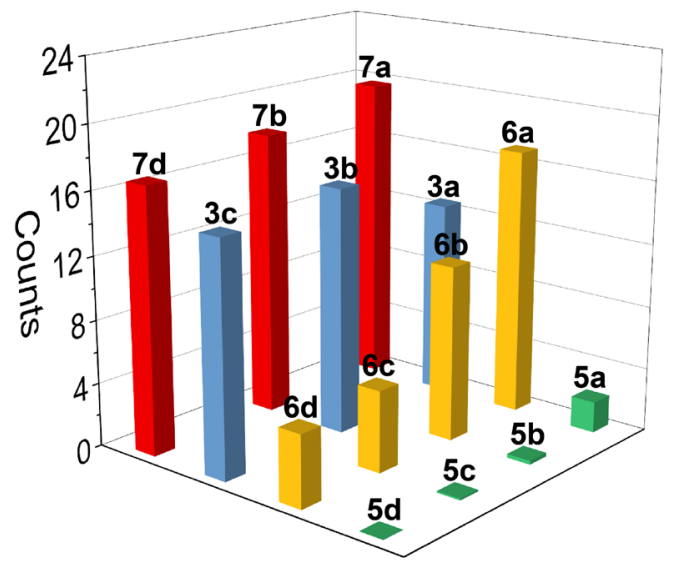

Figure S9. The average numbers of each alkyne substrate calculated inside the SCNP-2 size cutoff during MD simulation.

\section{Protein Binding Free Energy.}

The protein structure of bovine serum albumin (PDB ID: 3V03) was obtained through PDB databank (https://www.rcsb.org/structure/3v03). The protein structure of avidin (PDB ID: 5MYQ) was obtained through PDB databank (https://www.rcsb.org/structure/5MYQ). Missing residues and missing atoms in the original structures were fixed using pdbfixer (https://github.com/pandegroup/pdbfixer). Binding free energy $\Delta \mathrm{G}$ between the protein and the nanoparticle is estimated as the non-equilibrium work $\mathrm{W}$ done by pulling the bind state into the separating state. In principle, we could fix the protein at its original position, and pull the nano-particle away from it infinitely slowly, the non-equilibrium work would correspond to 
the reversible work $\mathrm{W}_{\text {rev }}$, and the Jarzynski relation reduces to the binding free energy $\Delta \mathrm{G}=\mathrm{W}_{\text {rev }} \cdot{ }^{14} \mathrm{In}$ our simulation, we constrain each protein atom at its initial position using a harmonic potential with force constant $1000 \mathrm{~kJ} \cdot \mathrm{mol}^{-1} \cdot \mathrm{nm}^{-2}$, nano-particle is free to move, and is slowly pulled away from the protein using an umbrella pulling scheme in Gromacs, with a force constant $6000 \mathrm{~kJ} \cdot \mathrm{mol}^{-1} \cdot \mathrm{nm}^{-2}$. Since we perform a single (slow) non-equilibrium pulling calculation we estimate the free energy of association as $\mathrm{W}=\int \mathrm{fdx} \geqslant \Delta \mathrm{G}$, where our calculated non-equilibrium work provides a semi-quantitative estimate and upper bound to the true free energy difference that would be computed for infinitely slow pulling. The simulation was conducted in a box with the size of $10 \times 10 \times 22 \mathrm{~nm}$. To mimic the condition of PBS buffer, the box was added with $215 \mathrm{Na}^{+}$ion, $186 \mathrm{Cl}^{-}$ion, $13 \mathrm{HPO}_{4}{ }^{2-}$ ion, $3 \mathrm{H}_{2} \mathrm{PO}_{4}^{-}$ion and water. For BSA protein, the center of mass distance (CMD) between the protein and nano-particle at the initial binding state is 2.48 $\mathrm{nm}$, after pulling, the CMD became $8.32 \mathrm{~nm}$ in the separated state. For avidin protein, due to the different protein size and shape, the simulation was performed from CMD equal $3.60 \mathrm{~nm}$ to $9.55 \mathrm{~nm}$. The pulling speed is about $0.6 \mathrm{~nm} / \mathrm{ns}$, and last for $10 \mathrm{~ns}$. In estimating the non-equilibrium work through the force integral, we subtract out from the measured force the portion that is due to performing work on the solvent. We estimate this correction force from the approximately constant value of the force that is observed for large CMD separations where the two macromolecules are effectively non-interacting and the only contribution to the observed force is due to the solvent.

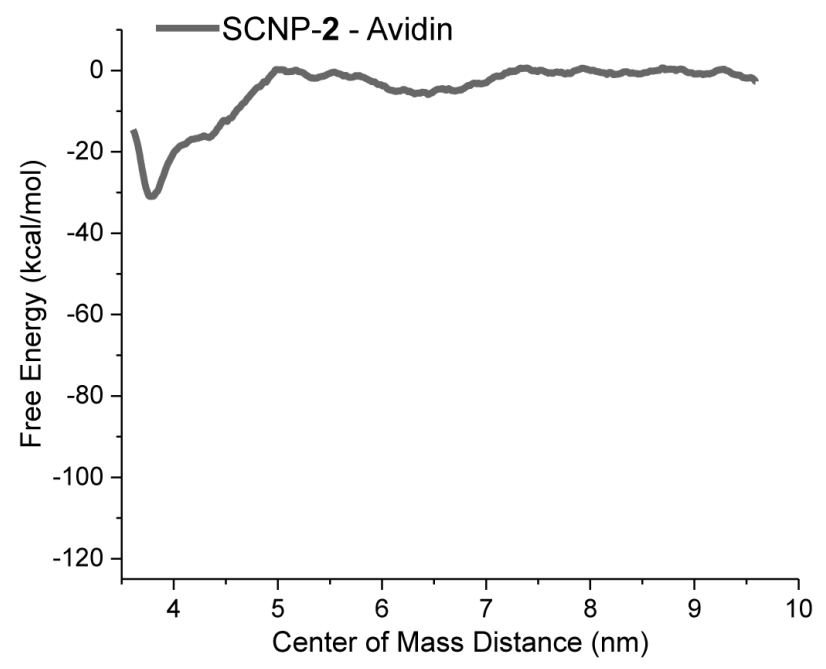

Figure S10. MD simulation between a single SCNP-2 and avidin protein, and the free energy was calculated with the center of mass distance from $3.6 \mathrm{~nm}$ to $9.6 \mathrm{~nm}$. 


\section{Click Catalysis on Proteins}

\section{Protein Functionalization with Alkyne Groups}

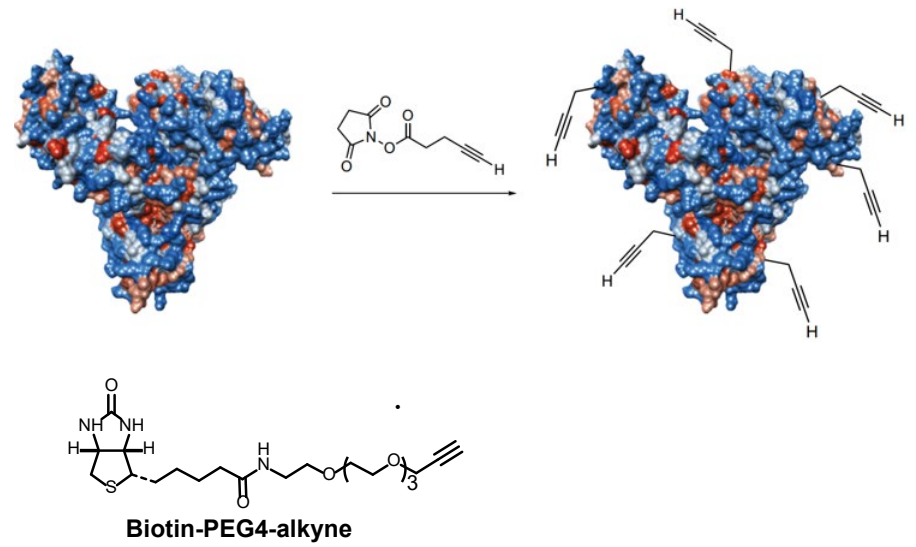

\begin{tabular}{|c|c|c|c|c|}
\hline Proteins & $\begin{array}{c}\text { Total Numbers of } \\
\text { Amine Residues }\end{array}$ & $\begin{array}{c}\text { Mw Before } \\
\text { Modification }\end{array}$ & $\begin{array}{c}\text { Mw After } \\
\text { Modification }\end{array}$ & $\begin{array}{c}\text { Average Numbers } \\
\text { of Alkynes }\end{array}$ \\
\hline BSA & 60 & 66390 & 67411 & 13 \\
\hline HSA & 60 & 66304 & 67351 & 13 \\
\hline ProteinA & 41 & 46529 & 47319 & 10 \\
\hline mCherry & 15 & 29716 & 30257 & 7 \\
\hline Transferrin & 66 & 78860 & 79823 & 12 \\
\hline Lysozyme & 16 & 14323 & 14513 & 2 \\
\hline
\end{tabular}
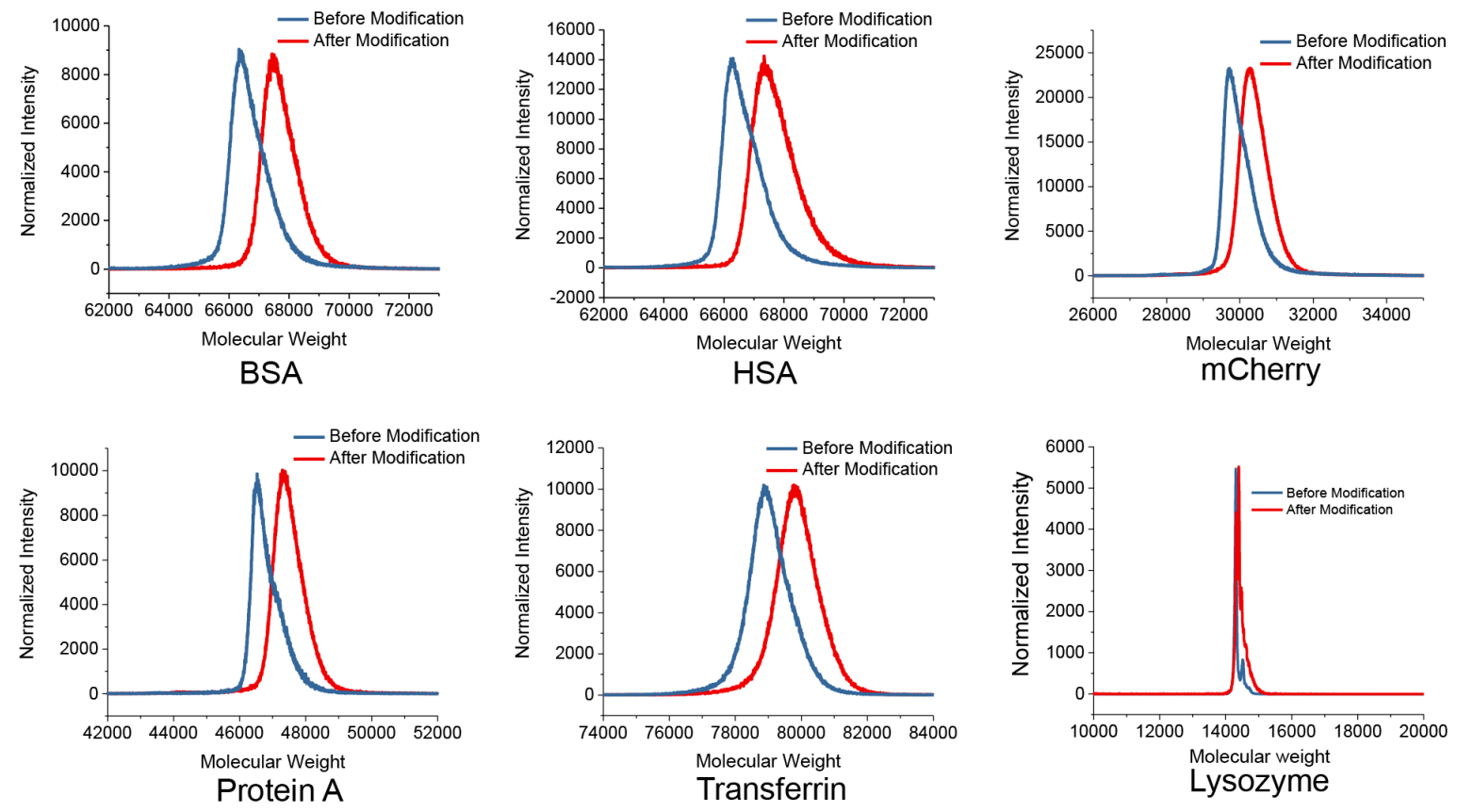

Figure S11. MALDI spectra of proteins before and after functionalization and the average numbers of alkyne groups on each protein. 


\section{Fluorogenic Reaction on Proteins}
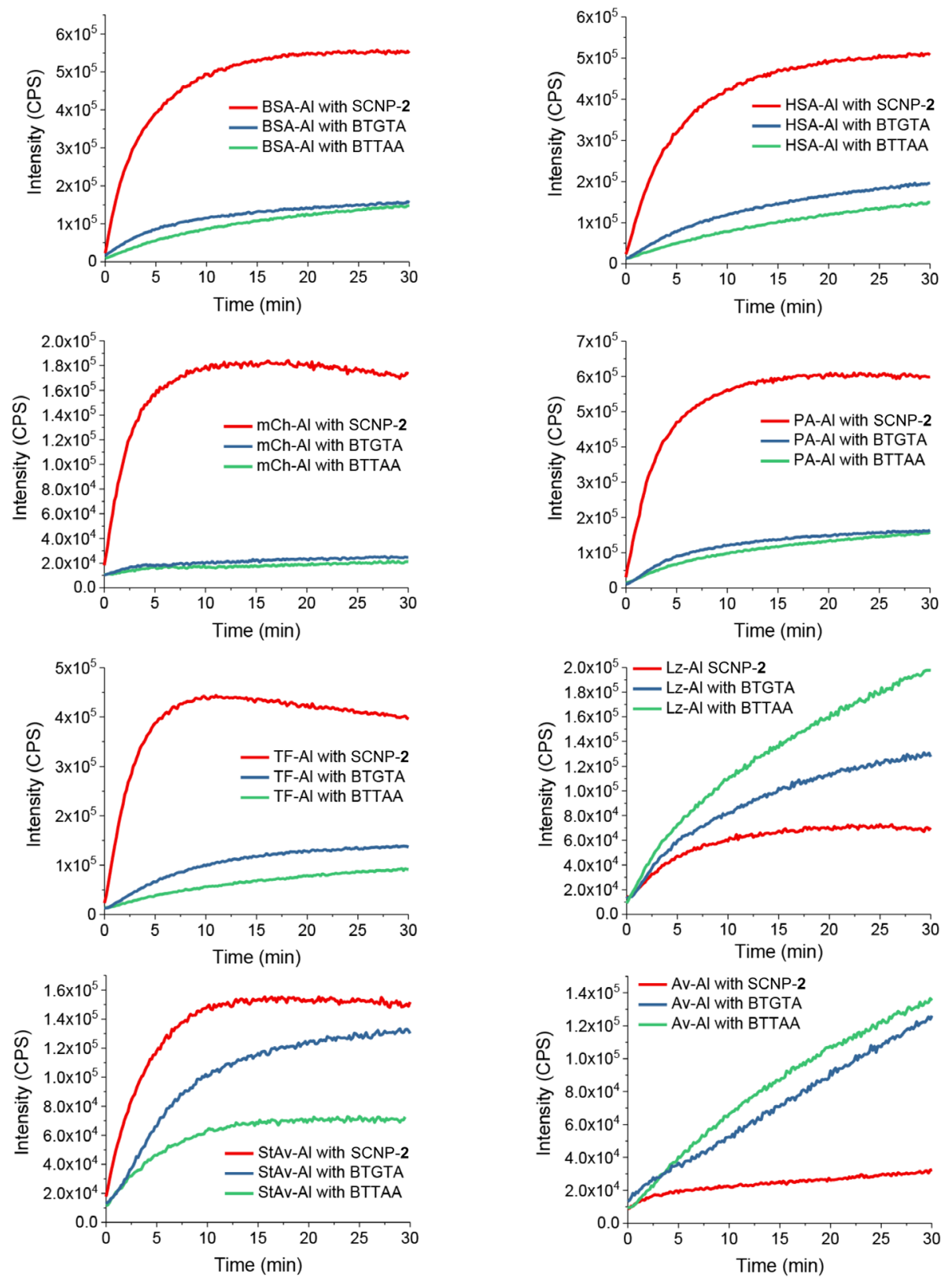

Figure S12. Reaction kinetics monitored by fluorimeter. Reactions were conducted in PBS buffer (1x, $\mathrm{pH}=7.4)$ at room temperature with $\mathrm{Cu}^{\mathrm{I}}-\mathrm{SCNP}-2(2 \mu \mathrm{M})$ or $\mathrm{Cu}^{\mathrm{I}}$-BTTAA $(20 \mu \mathrm{M})$ or $\mathrm{Cu}^{\mathrm{I}}$-BTGTA, $2(40$ $\mu \mathrm{M})$, protein $(2 \mu \mathrm{M}$ for BSA-Al, HSA-Al, mCh-Al, PA-Al, TF-Al, StAv-Al and Av-Al, and $5 \mu \mathrm{M}$ for $\mathrm{Lz}-\mathrm{Al})$ and sodium ascorbate $(2 \mathrm{mM})$. 


\section{MALDI Spectrum of BSA after CuAAC Reaction}

In a $1.5 \mathrm{~mL}$ centrifuge tube, the reaction was conducted in $1 \mathrm{~mL}$ of PBS buffer $(1 \mathrm{x}, \mathrm{pH}=7.4)$ with BSA-A1 $(2 \mu \mathrm{M}), 2(40 \mu \mathrm{M}), \mathrm{Cu}^{\mathrm{I}}-\mathrm{SCNP}-2(2 \mu \mathrm{M})$ and sodium ascorbate $(2 \mathrm{mM})$ at room temperature for $30 \mathrm{~min}$. After the reaction, EDTA was added to reach the concentration of $2 \mathrm{mM}$ to remove copper. The solutions were passed through a cation exchange spin column to remove SCNP-2, and the BSA protein was eluted out by using PBS buffer. The resulting protein solution was concentrated through Amicon tube with $10 \mathrm{kDa}$ cutoff. The molecular weight of the product protein was determined through MALDI spectrum (Figure S13).

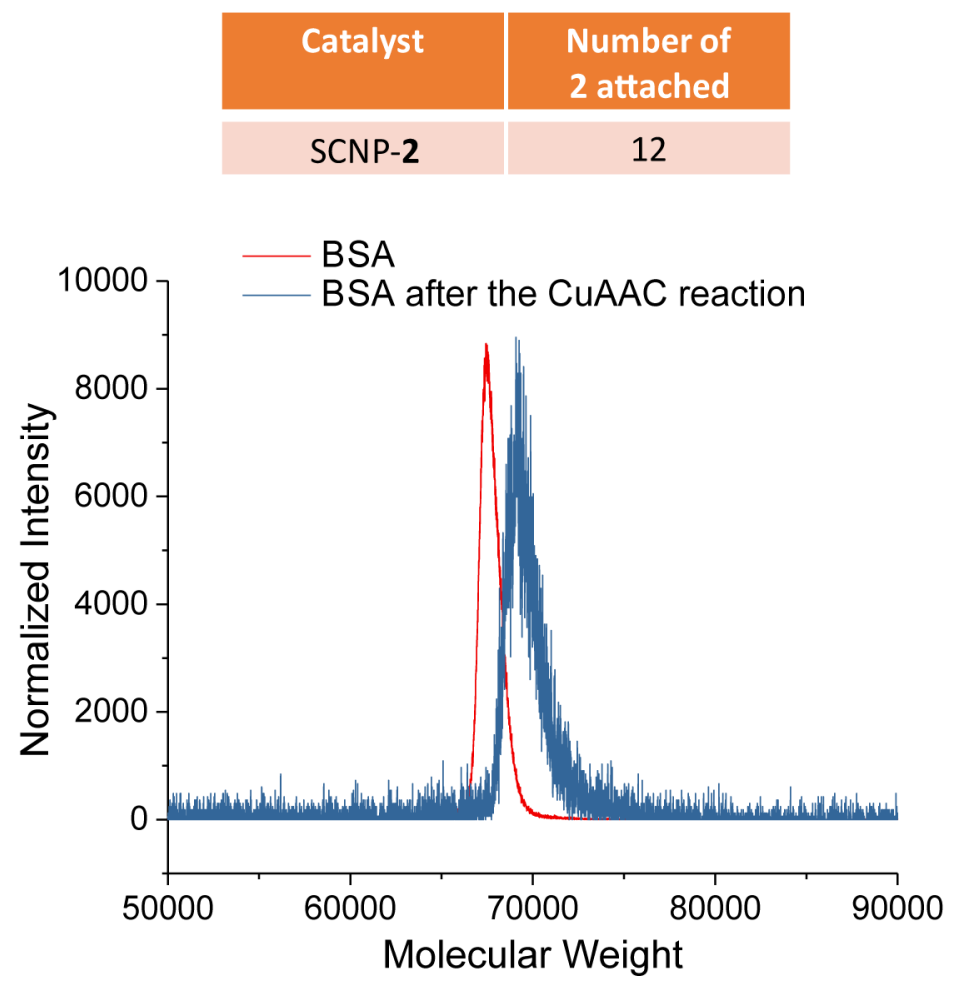

Figure S13. MALDI spectra of BSA-Al before and after the CuAAC reactions in PBS buffer. 


\section{SDS Gel Experiment}

The SDS gel experiment was conducted for the reaction mixture of BSA-Al, HSA-Al, PA-Al, mCh-Al and TF-Al. The reaction mixture was prepared in a $0.5 \mathrm{~mL}$ centrifuge tube, and the reactions were conducted between protein $(2 \mu \mathrm{M})$ and $2(40 \mu \mathrm{M})$ catalyzed by Cu$u^{\mathrm{I}}-\mathrm{SCNP}-2(2 \mu \mathrm{M}) \mathrm{Cu}^{\mathrm{I}}-\mathrm{BTTAA}(20 \mu \mathrm{M})$ or $\mathrm{Cu}^{\mathrm{I}}-$ BTGTA $(20 \mu \mathrm{M})$ in $0.2 \mathrm{~mL}$ of PBS buffer $(1 \mathrm{x}, \mathrm{pH}=7.4)$ for $10 \mathrm{~min}$ at room temperature. The ascorbic acid concentration was $2 \mathrm{mM}$ and the final amount of DMSO was $2 \%(\mathrm{v} / \mathrm{v})$. After the reaction, $10 \mu \mathrm{L}$ of the solution was mixed with SDS loading buffer $(10 \mu \mathrm{L})$. The sample was heated at $95{ }^{\circ} \mathrm{C}$ for 5 min, and 7 $\mu \mathrm{L}$ of the mixture was added per lane on SDS-PAGE separation. After separation, gels were scanned at 530 $\mathrm{nm}$ with $28 \mathrm{~nm}$ bandpass filter on a Bio-Rad ChemiDoc MP Imager using UV Trans illumination (Figure S14).
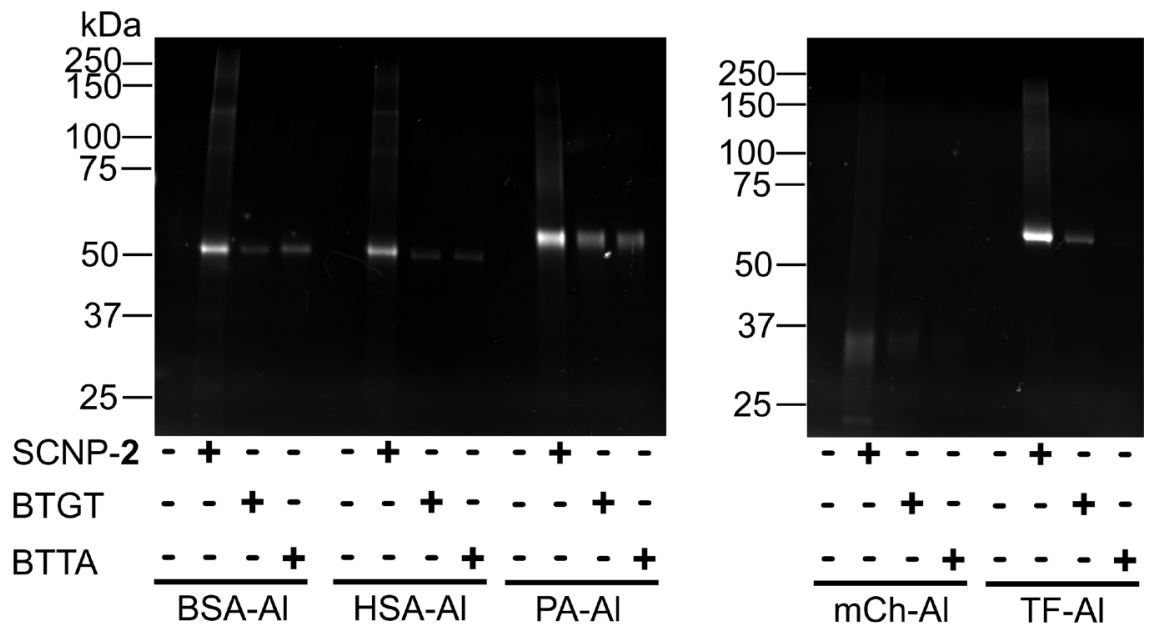

Figure S14. In gel fluorescence images of proteins after the reactions. 


\section{DLS Data of the Mixture of BSA-Al and SCNP-2}

DLS experiments were performed on the mixture of Cu-SCNP-2 $(2 \mu \mathrm{M})$, BSA-Al $(2 \mu \mathrm{M}), 2(40 \mu \mathrm{M})$ and sodium ascorbate $(2 \mathrm{mM})$ in PBS buffer or BSA-Al $(2 \mu \mathrm{M})$ alone in PBS buffer. The results are shown in Figure S15, and the DLS signal for SCNP-2 was adapted from Figure 1c. A weak tail was observed in the sample containing both BSA and SCNP-2. This signal may be attributed to the complex formed by BSA and SCNP-2, because the nanoparticle can weakly and reversibly bind to the protein.

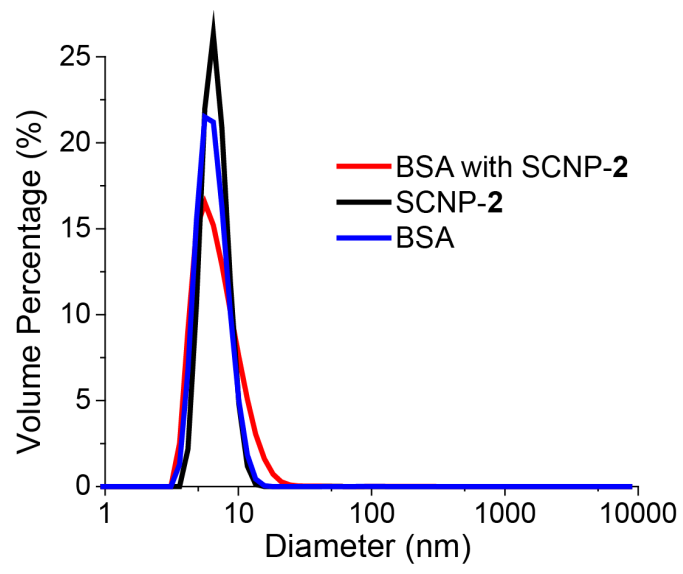

Figure S15. DLS signals of BSA-Al $(2 \mu \mathrm{M})$, SCNP-2 $(25 \mu \mathrm{M})$ and the reaction mixture with $\mathrm{Cu}^{\mathrm{I}}-$ SCNP-2 $(2 \mu \mathrm{M}), 2(40 \mu \mathrm{M}), \mathrm{BSA}-\mathrm{Al}(2 \mu \mathrm{M})$ and sodium ascorbate $(2 \mathrm{mM})$ in PBS buffer $(1 \mathrm{x}, \mathrm{pH}=$ 7.4). 


\section{FRET Experiment}

In a $0.7 \mathrm{~mL}$ glass vial for fluorometer, fluorescein labelled $\mathrm{Cu}^{\mathrm{II}}-\mathrm{SCNP}-3$ and rhodamine labelled BSA protein (BSARh) were mixed in PBS buffer to reach different final concentrations. The fluorescence spectra were measured immediately after mixing the solution with ex $=470 \mathrm{~nm}$, em $=500-650 \mathrm{~nm}$, slit $=2 \mathrm{~nm}$. The fluorescence spectra remain unchanged after $10 \mathrm{~min}$ indicating it was a fast binding process. To measure the reversibility of the binding, three experiments were conducted by mixing $\mathrm{Cu}^{\mathrm{II}}-\mathrm{SCNP}-3$, BSARh and BSA protein at different order, and the fluorescence spectra were taken with the above condition.

1. $\mathrm{Cu}^{\mathrm{II}}-\mathrm{SCNP}-3(2 \mathrm{uM})$ were mixed with BSA-Rh $(2 \mathrm{uM})$ for 1 min and BSA $(16 \mathrm{uM})$ was added and mixed.

2. $\mathrm{Cu}^{\mathrm{II}}-\mathrm{SCNP}-3(2 \mathrm{uM})$ were mixed with BSA $(16 \mathrm{uM})$ for $1 \mathrm{~min}$ and $\mathrm{BSA}-\mathrm{Rh}(2 \mathrm{uM})$ was added and mixed.

3. BSA $(16 \mathrm{uM})$ were mixed with BSA-Rh $(2 \mathrm{uM})$ for $1 \mathrm{~min}$ and $\mathrm{Cu}^{\mathrm{II}}-\mathrm{SCNP}-3(2 \mathrm{uM})$ was added and mixed.
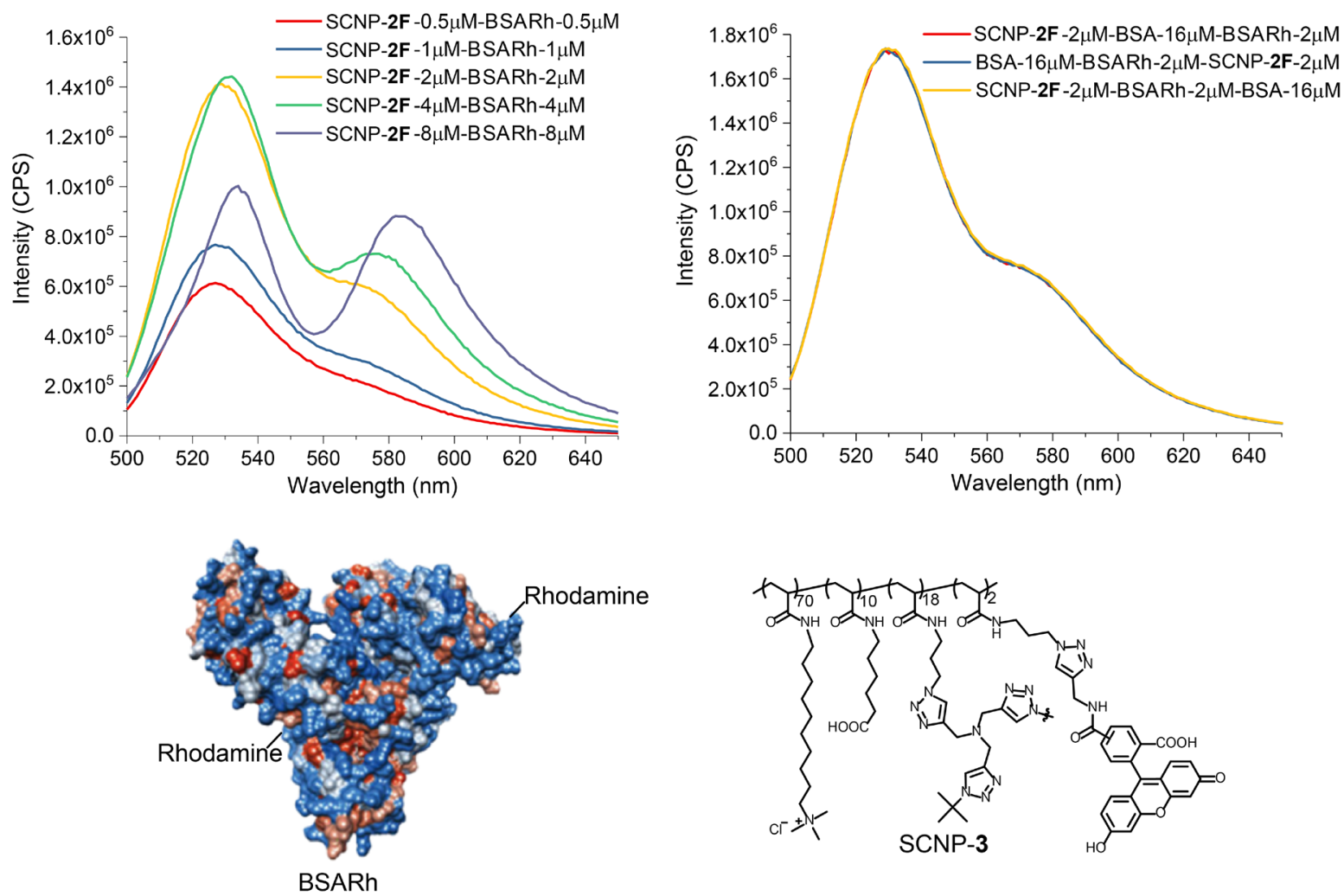

Figure S16. Fluorescence spectra of FRET experiments in PBS buffer $(1 \mathrm{x}, \mathrm{pD}=7.4)$ with $\mathrm{Cu}^{\mathrm{II}}-\mathrm{SCNP}-$ 2F, BSARh and unlabeled BSA protein at different concentration and addition order. ex $=470 \mathrm{~nm}$, slit $=2 \mathrm{~nm}$. 


\section{Spectrum}

In a $1.5 \mathrm{~mL}$ centrifuge tube, each type of proteins was dissolved in $1 \mathrm{~mL}$ of $\mathrm{PBS}$ buffer $(1 \mathrm{x}, \mathrm{pH}=7.4)$ at the concentration of $2 \mu \mathrm{M}$ with/without $\mathrm{Cu}^{\mathrm{II}}$-SCNP-2 $(2 \mu \mathrm{M})$ and left at room temperature for $1 \mathrm{~h}$. The solution $(600 \mu \mathrm{L})$ was transferred to a crystal cuvette, and spectra were collected by using a J-715 spectrometer (Jasco) with a Peltier-controlled cuvette holder (Jasco). Spectra were measured from 250nm to $200 \mathrm{~nm}$ at $20^{\circ} \mathrm{C}$ with a scanning speed of $50 \mathrm{~nm} / \mathrm{min}$. Final spectra were averages of 3 accumulations. The experiment data was processed using OriginPro2017 for spectra comparison (Figure S17).

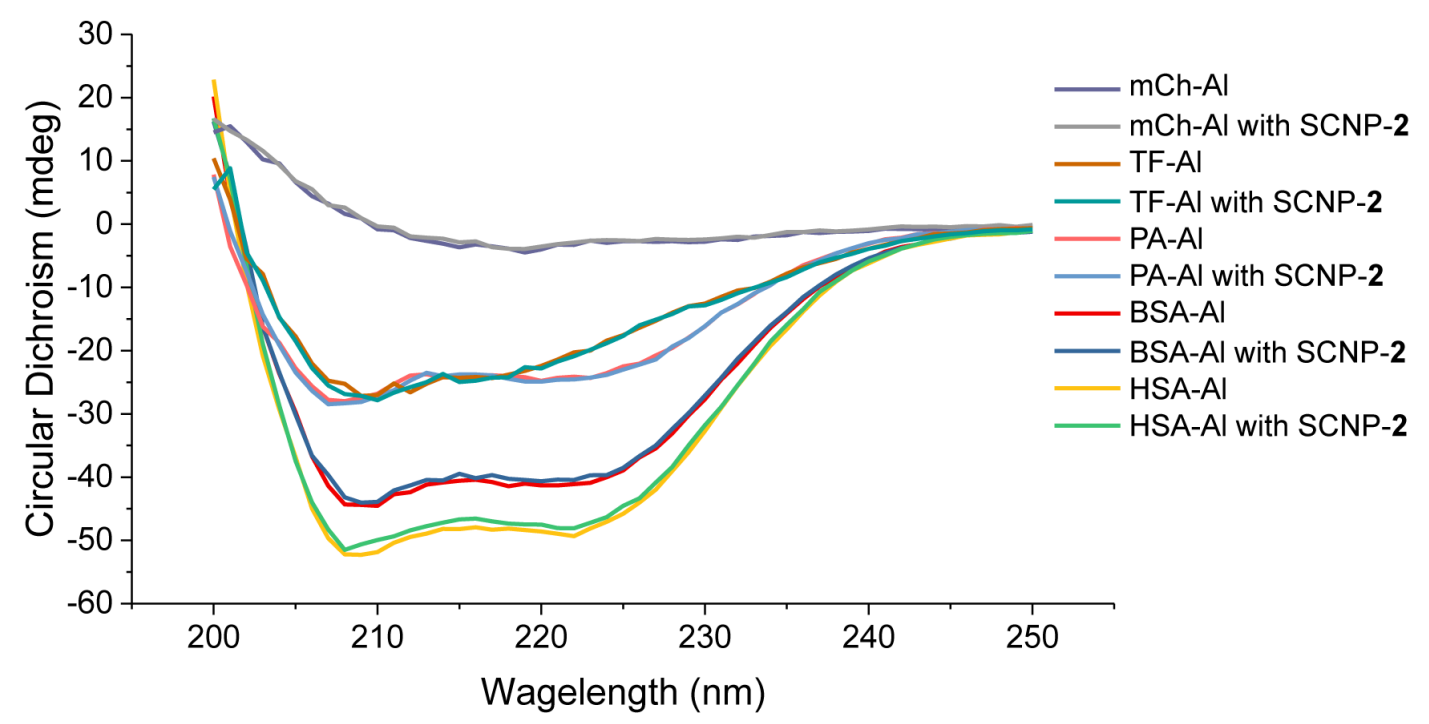

Figure S17. CD spectra of proteins $(2 \mu \mathrm{M})$ with/without $\mathrm{Cu}^{\mathrm{II}}-\mathrm{SCNP}-2(2 \mu \mathrm{M})$ in PBS buffer $(1 \mathrm{x}, \mathrm{pH}=$ 7.4). 


\section{Metabolic Labelled Protein Extract}
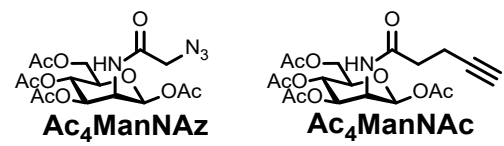

To HeLa and H460 cells at 80-90\% confluency, the media was changed to fresh DMEM media (10\% FBS) with $\mathrm{Ac}_{4} \mathrm{ManNAl}(200 \mu \mathrm{M})$ added as $500 \mathrm{x}$ stock solution in DMSO. Cells were incubated at $37^{\circ} \mathrm{C}$ with $5 \%$ $\mathrm{CO}_{2}$ for $16 \mathrm{~h}$ for metabolic incorporation. Cells were detached by trypsinization and centrifuged down for $5 \mathrm{~min}$ at $1000 \mathrm{~g}$ at $4{ }^{\circ} \mathrm{C}$. The cell pellets were washed with $10 \mathrm{~mL}$ of PBS buffer $(1 \mathrm{x}, \mathrm{pH}=7.4)$ twice, and resuspended in $500 \mu \mathrm{L}$ of $1 \% \mathrm{NP}-40$ lysis buffer $(1 \% \mathrm{NP}-40,150 \mathrm{mM} \mathrm{NaCl}, 50 \mathrm{mM}$ triethanolamine, $\mathrm{pH}=$ 7.4, with 1 tablet of Complete, Mini EDTA-free Protease Inhibitor Cocktail Tbalet Roche in $10 \mathrm{~mL}$ ] for 20 min, and the suspension was centrifuged at $10000 \mathrm{~g}$ for $10 \mathrm{~min}$ at $4^{\circ} \mathrm{C}$. Small molecules in the supernatant was removed through an Amicon tube with $3 \mathrm{kDa}$ cutoff. The concentration of protein was determined through UV absorption at $280 \mathrm{~nm}$ and normalized to $1 \mathrm{mg} / \mathrm{mL}$ where the absorption at $280 \mathrm{~nm}$ equal 1 .

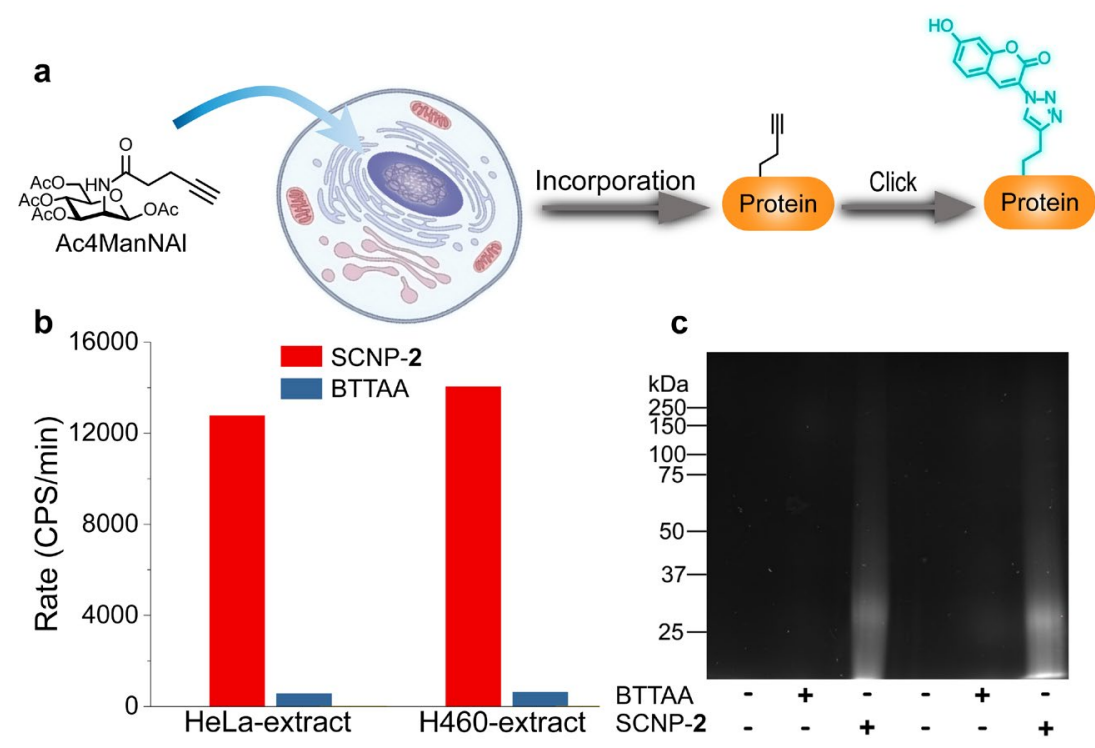

Figure S18. a, illustration of metabolic labelling of glycoproteins by using $\mathrm{Ac}_{4} \mathrm{ManNA1}$. b, reaction rates on $0.5 \mathrm{mg} / \mathrm{mL}$ of cell protein extracts with $\mathrm{Cu}^{\mathrm{I}}-\mathrm{SCNP}-2(10 \mu \mathrm{M})$ or $\mathrm{Cu}^{\mathrm{I}}-\mathrm{BTTAA}(100 \mu \mathrm{M}), 2(20$ $\mu \mathrm{M})$ and sodium ascorbate $(2 \mathrm{mM})$ in PBS buffer $(1 \mathrm{x}, \mathrm{pH}=7.4)$. $\mathbf{c}$, in gel fluorescence image of SDSPAGE gel of the mixture in $\mathbf{b}$ after 10 min of the reaction. 


\section{Cellular Study}

\section{Cell surface glycan labelling}

For the experiment conducted between alkyne labelled H460 cells and fluorogenic probe 2 (Figure S19a and $19 \mathrm{~b}), \mathrm{Cu}^{\mathrm{I}}$-SCNP-2 successfully catalyzed the reaction and "lighted up" the cell membrane. In contrast, $\mathrm{Cu}^{\mathrm{I}}$-BTGTA and $\mathrm{Cu}^{\mathrm{I}}$-BTTAA showed almost no activity, and only autofluorescence was observed inside the cells. During the reaction between azido labelled H460 cellls and mCh-Al, the nanoparticle may stick $\mathrm{mCh}-\mathrm{Al}$ and cell membrane together and subsequently performed the click reaction. This characteristic of polycationic polymers has been utilized for protein delivery ${ }^{15}$. Indeed, some potential protein internalization in the control experiment where the cells were not added with Ac4ManNaz was observed (Figure S19c and $19 d)$.

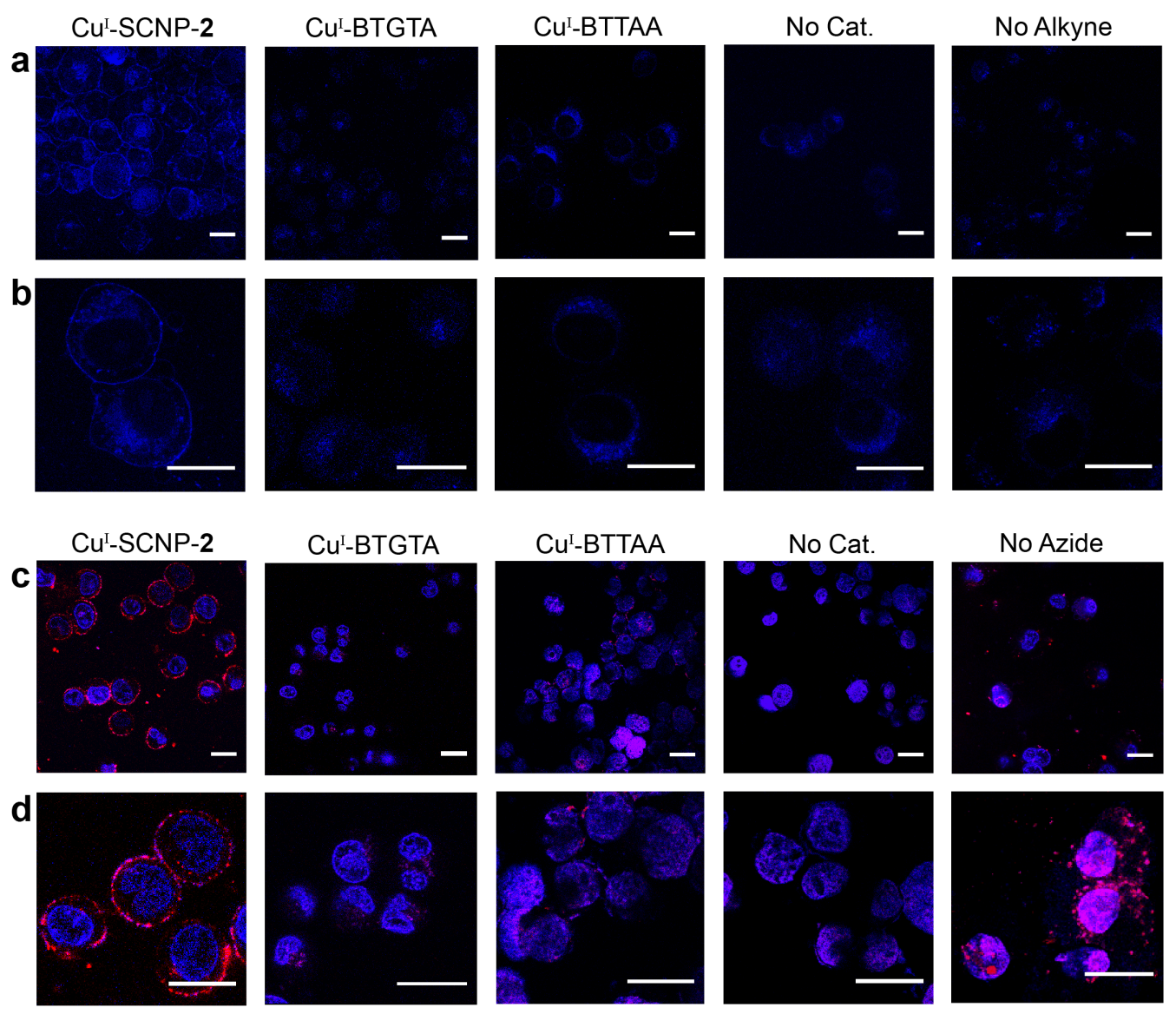

Figure S19. Confocal images for cell surface glycan imaging. a,b, confocal images of alkyne labelled H460 cell treated with $\mathrm{Cu}^{\mathrm{I}}$-SCNP-2 $(1 \mu \mathrm{M}), \mathrm{Cu}^{\mathrm{I}}$-BTGTA $(10 \mu \mathrm{M})$ or Cu $\mathrm{Cu}^{\mathrm{I}}$-BTTAA $(10 \mu \mathrm{M})$ or without catalyst, $2(100 \mu \mathrm{M})$ and sodium ascorbate $(2 \mathrm{mM})$ in PBS buffer $(1 \mathrm{x}, \mathrm{pH}=7.4)$ for $30 \mathrm{~min}$. "No Alkyne" was native $\mathrm{H} 460$ cell treated with $\mathrm{Cu}^{\mathrm{I}}-\mathrm{SCNP}-2(1 \mu \mathrm{M}), 2(100 \mu \mathrm{M})$ and sodium ascorbate $(2$ $\mathrm{mM})$ in PBS buffer $(1 \mathrm{x}, \mathrm{pH}=7.4)$. $\mathbf{c}, \mathbf{d}$, confocal images of azide labelled $\mathrm{H} 460$ cell treated with $\mathrm{Cu}^{\mathrm{I}}-$ SCNP-2 $(1 \mu \mathrm{M})), \mathrm{Cu}^{\mathrm{I}}$-BTGTA $(10 \mu \mathrm{M})$ or Cu -BTTAA $(10 \mu \mathrm{M})$ or without catalyst, mCh-Al $(1 \mu \mathrm{M})$ and sodium ascorbate $(2 \mathrm{mM})$ in PBS buffer $(1 \mathrm{x}, \mathrm{pH}=7.4)$ for $30 \mathrm{~min}$. "No Azide" was native H460 cell treated with $\mathrm{Cu}^{\mathrm{I}}$-SCNP-2 $(1 \mu \mathrm{M}), \mathrm{mCh}-\mathrm{Al}(1 \mu \mathrm{M})$ and sodium ascorbate $(2 \mathrm{mM})$ in PBS buffer $(1 \mathrm{x}$, $\mathrm{pH}=7.4)$. Nucleus were stained with Hoechst for images $\mathbf{c}$ and $\mathbf{d}$.Scale bar $=20 \mu \mathrm{m}$. 


\section{Cell Viability Assay}

In a 96-wells plate, 10000 of HeLa or H460 cells in $0.1 \mathrm{~mL}$ of DMEM media (10\% FBS) was added to each well and incubated at $37^{\circ} \mathrm{C}$ with $5 \% \mathrm{CO}_{2}$ for $24 \mathrm{~h}$. The cell media was removed, and each well was washed with $100 \mu \mathrm{L}$ of PBS buffer $(1 \mathrm{x}, \mathrm{pH}=7.4)$ for three times. Then $100 \mu \mathrm{L}$ of PBS buffer $(1 \mathrm{x}, \mathrm{pH}=7.4)$ containing $\mathrm{Cu}^{\mathrm{I}}$-SCNP-2 from $0.5 \mu \mathrm{M}$ to $2 \mu \mathrm{M}$ and $2 \mathrm{mM}$ sodium ascorbate was added, and the cells were incubated at $37^{\circ} \mathrm{C}$ with $5 \% \mathrm{CO}_{2}$ for $30 \mathrm{~min}$. For the control experiment, the cells were incubated with PBS buffer $(1 \mathrm{x}, \mathrm{pH}=7.4)$ at $37{ }^{\circ} \mathrm{C}$ with $5 \% \mathrm{CO}_{2}$ for $30 \mathrm{~min}$. The solution was removed, and each well was washed with $100 \mu \mathrm{L}$ PBS buffer $(1 \mathrm{x}, \mathrm{pH}=7.4)$ for three times. Then $100 \mu \mathrm{L}$ of DMEM media $(10 \% \mathrm{FBS})$ was added to each well and incubated for $24 \mathrm{~h}$. The cell viability was measured using MTT assay.

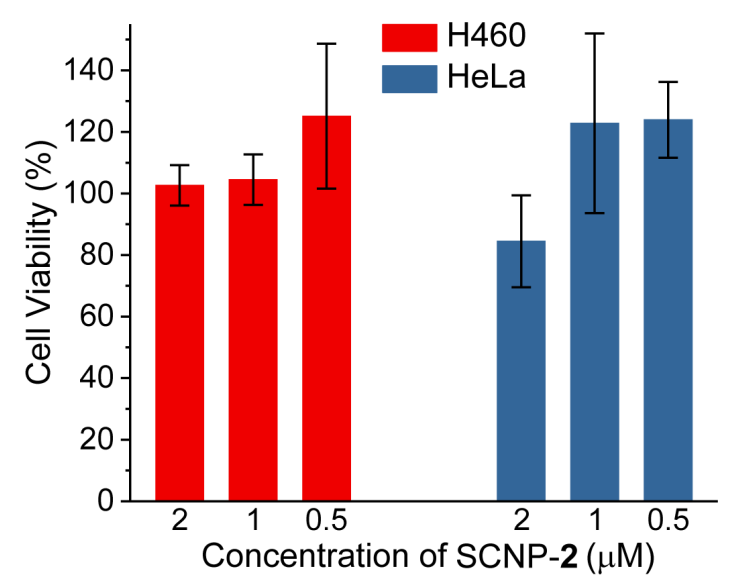

Figure S20. Cell viability of HeLa and $\mathrm{H} 460$ cells after treating with different concentrations of $\mathrm{Cu}^{\mathrm{I}}-$ SCNP-2. 


\section{$\underline{\text { NMR Spectra of Polymers }}$}

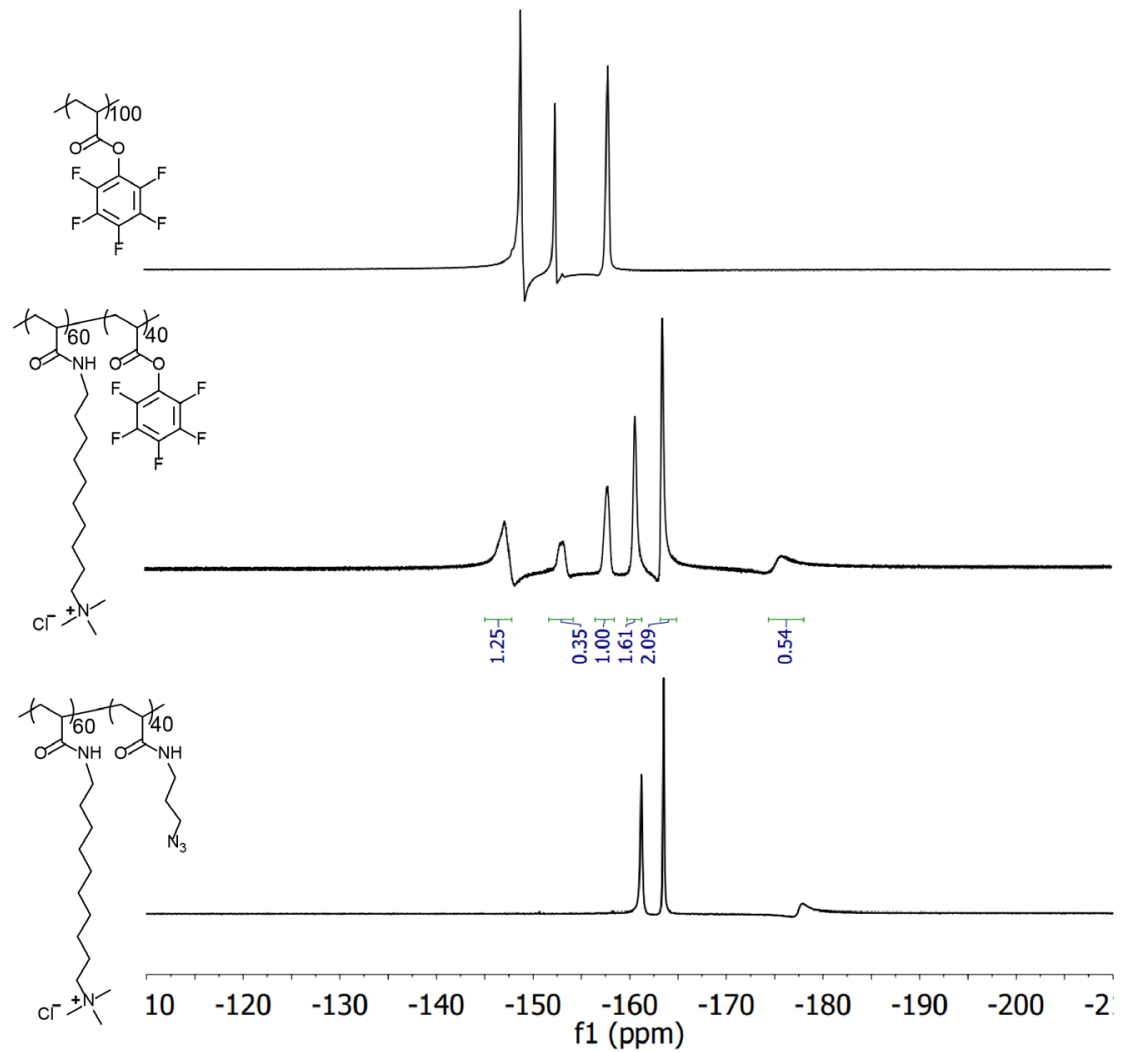

Figure S21. ${ }^{19}$ FNMR spectra of $\mathrm{P} 1$ and unpurified $\mathrm{P} 4$ in the mixture of $\mathrm{CDCl}_{3}$ and DMSO-d6 $(2: 1$, $\mathrm{v} / \mathrm{v}$ ).
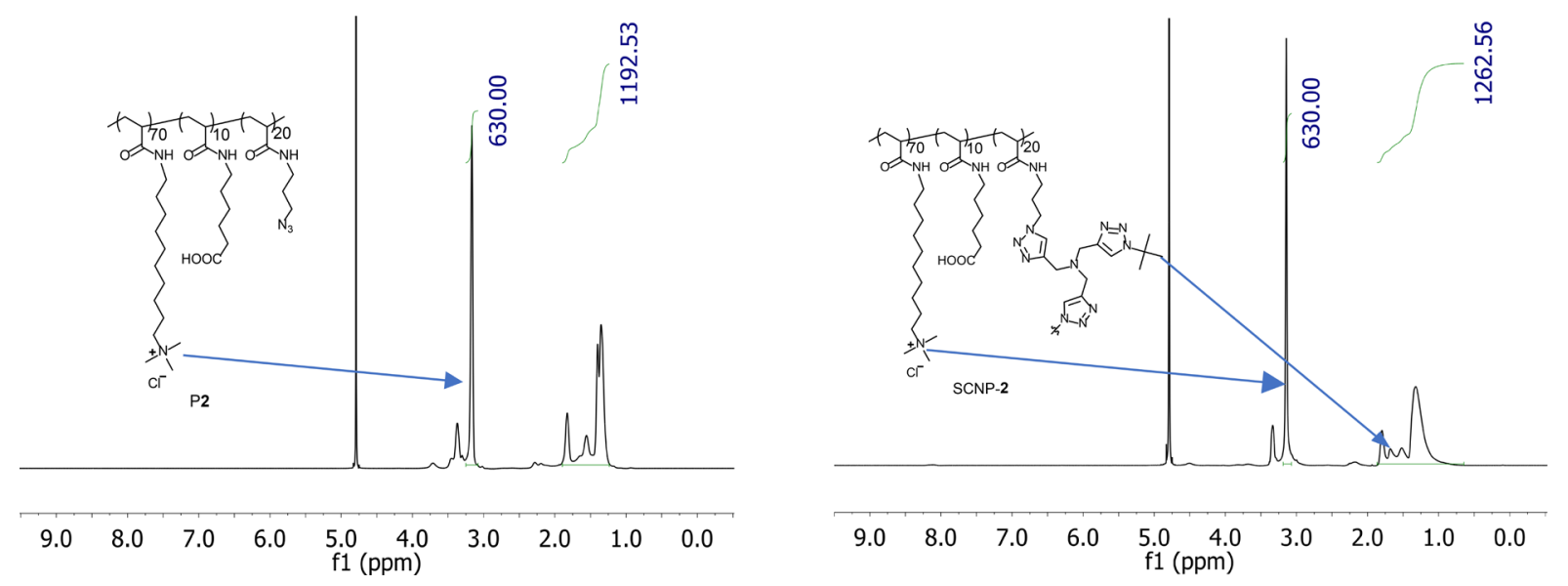

Figure S22. ${ }^{1} \mathrm{HNMR}$ spectra of $\mathrm{P} 2$ and $\mathrm{SCNP}-2$ in $\mathrm{D}_{2} \mathrm{O}$. 

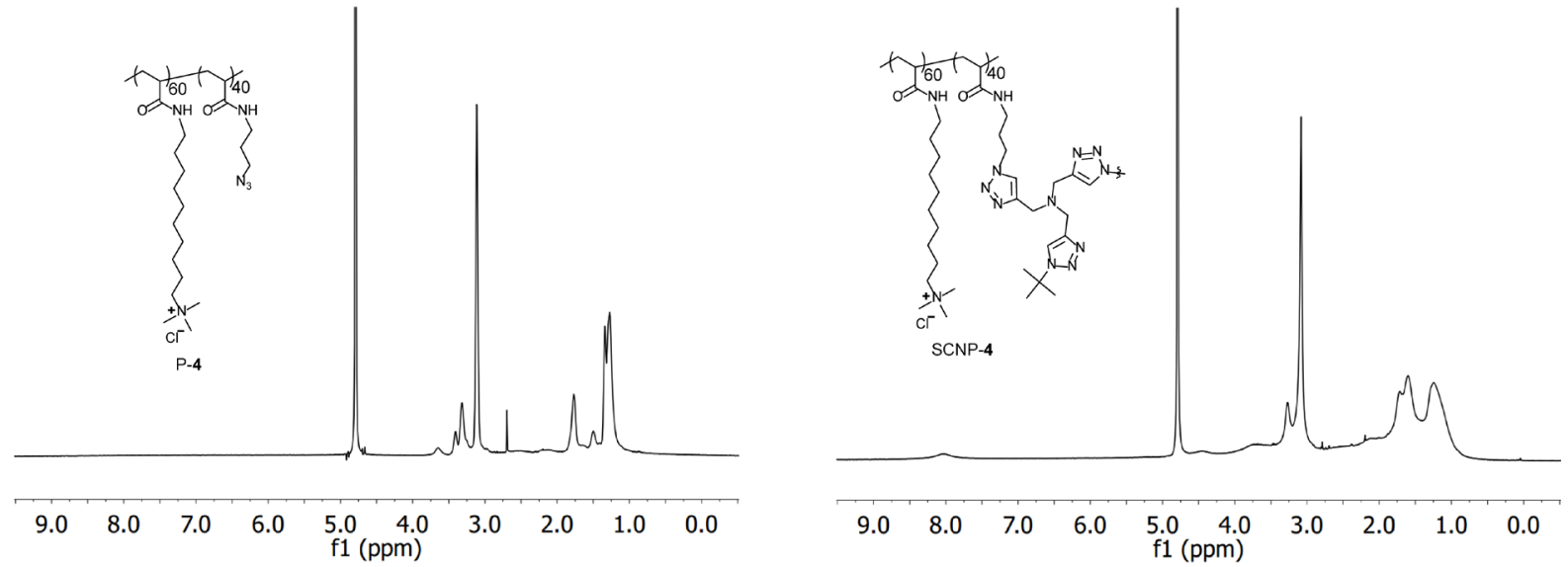

Figure S23. ${ }^{1} \mathrm{HNMR}$ spectra of $\mathrm{P}-4$ and $\mathrm{SCNP}-4$ in $\mathrm{D}_{2} \mathrm{O}$.
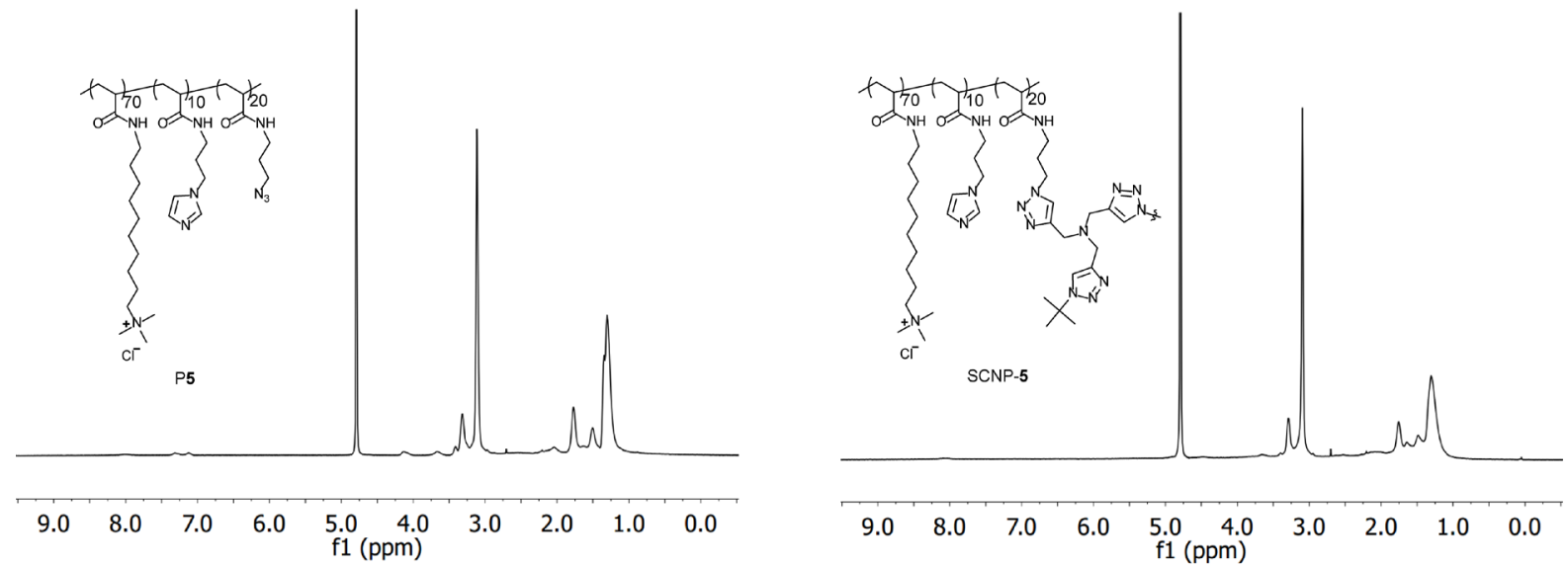

Figure S24. ${ }^{1} \mathrm{HNMR}$ spectra of $\mathrm{P} 5$ and $\mathrm{SCNP}-5$ in $\mathrm{D}_{2} \mathrm{O}$.
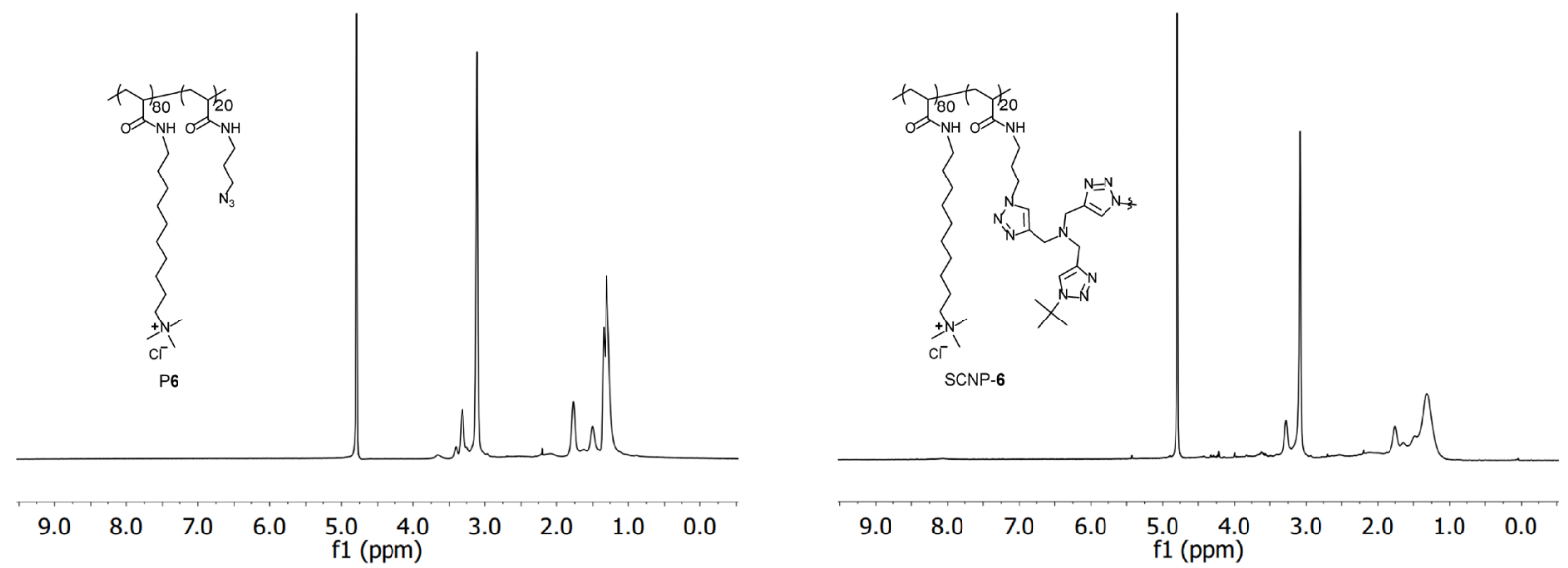

Figure S25. ${ }^{1} \mathrm{HNMR}$ spectra of $\mathrm{P} 6$ and SCNP-6 in $\mathrm{D}_{2} \mathrm{O}$. 


\section{References:}

1. D. Soriano del Amo, W. Wang, H. Jiang, C. Besanceney, A. C. Yan M. Levy, Y. Liu, F. L. Marlow, P. $\mathrm{Wu}$, Biocompatible Copper(I) Catalysts for in Vivo Imaging of Glycans. J. Am. Chem. Soc. 132, 1689316899 (2010)

2. J. Chen, J. Wang, Y. Bai, E. S. Garcia, A. L. Ferguson, S. C. Zimmerman, Enzyme-like Click Catalysis by a Copper-Containing Single-Chain Nanoparticle. J. Am. Chem. Soc. 140, 13695-13702 (2018).

3. A. K. Malde, L. Zuo, M. Breeze, M. Stroet, D. Poger, P. C. Nair, C. Oostenbrink, A. E Mark, An Automated Force Field Topology Builder (ATB) and Repository: Version 1.0. J. of Chem. Theory Comput. 7, 4026-4037 (2011).

4. N. Schmid, A. P. Eichenberger, A. Choutko, S. Riniker, M. Winger, A. E. Mark, W. F. van Gunsteren, Definition and testing of the GROMOS force-field versions 54A7 and 54B7. Eur. Biophys. J. 40, 843-856 (2011).

5. J. J. P. Stewart, MOPAC: A semiempirical molecular orbital program. J. Comput. Aided Mol. Des. 4, 1105 (1990).

6. B. Hess, C. Kutzner, D. van der Spoel, E. J. Lindahl, GROMACS 4: Algorithms for Highly Efficient, Load-Balanced, and Scalable Molecular Simulation. Chem. Theory Comput. 4, 435-447 (2008).

7. S. Pronk, S. Páll, R. Schulz, P. Larsson, P. Bjelkmar, R. Apostolov, M. R. Shirts, J. C. Smith, P. M. Kasson, D. van der Spoel, B. Hess, E. Lindahl, GROMACS 4.5: a high-throughput and highly parallel open source molecular simulation toolkit. Bioinformatics 29, 845-854 (2013).

8. M. P. Allen, D. J Tildesley, Computer Simulation of Liquids (Clarendon Press: New York, 1987).

9. U. Essmann, L. Perera, M. L. Berkowitz, T. Darden, H. Lee, L. G. Pedersen, A smooth particle mesh Ewald method. J. Chem. Phy. 103, 8577-8593 (1995).

10. B. Hess, H. Bekker, H. J. C. Berendsen, J. G. E. M. Fraaije, LINCS: A linear constraint solver for molecular simulations. J. Comput. Chem. 18, 1463-1472 (1997).

11. S. J. Nosé, A unified formulation of the constant temperature molecular dynamics methods. Chem. Phys. 81, 511-520 (1984).

12. M. Parrinello, A. Rahman, Polymorphic transitions in single crystals: A new molecular dynamics method. J. of Appl. Phys. 52, $7182-7191$ (1981).

13. R. W. Hockney, J. W. Eastwood, Computer Simulation Using Particles (CRC Press: Boca Raton, 2010).

14. C. Jarzynski, Nonequilibrium Equality for Free Energy Differences, Phys. Rev. Lett. 78, 2690-2693 (1997).

15. N. D. Posey, G. N. Tew, Chem. Asian J. 13, 3351-3365 (2018). 